\title{
LA PRODUCCIÓN REPUBLICANA DEL PLOMO EN EL ÁMBITO DEL Guadiana MEDIO
}

\author{
Francisco Javier Heras Mora \\ Junta de Extremadura
}

Recibido: 08/04/2016

Revisado: 21/04/2016
Aceptado: 22/04/2016

Publicado: 30/06/2016

\section{RESUMEN}

La producción de la plata en Hispania ha copado un lugar preeminente en los textos antiguos referidos al periodo republicano en la Península Ibérica y en la tradición historiográfica de la conquista romana. Sin embargo, el plomo no ha gozado de la misma atención, a pesar de que su geología, minería y procesos metalúrgicos guardan una relación muy íntima con aquélla. En este trabajo se incide en una dialéctica estrecha y continua entre ambos metales, confiriendo al plomo un papel muy relevante, protagonista en determinadas áreas geológicas e ineludible en la actividad de otras.

El análisis del registro arqueológico nos lleva a valorar el potencial de esta producción como "recurso estratégico", clave para entender la expansión romana en esta parte de Hispania. La actividad minero-metalúrgica, inserta en unas redes y circuitos industriales o empresariales, parece adquirir una proyección geográfica que escapa de esta parte de la fachada norte de Sierra Morena e inscribirse plenamente en la política económica de la propia Roma, obligada a defender sus intereses en cada momento.

Palabras Clave

minería; metalurgia; plomo; república; roma; hispania ulterior; economía; ejército.
ABSTRACT

The production of silver in Hispania has cornered a prominent place in the ancient texts referring to the Republican period in the Iberian Peninsula and in the historiographical tradition of the Roman conquest. However, lead has not enjoyed the same attention, despite its geology, mining and metallurgical processes that has a very close relationship with it. This paper is incident on a close and continuous dialectic between both metals, giving the lead a very important role, starring in certain geological and unavoidable activity in other areas.

The analysis of the archaeological record leads us to assess the potential of this production as "strategic resource", key to understanding the Roman expansion in this part of Hispania. The mining-metallurgical activities, performed in some industrial or business networks and circuits, seems to acquire a geographical projection that goes beyond this part of the north facade of Sierra Morena, fully joined with the economic policy of Rome itself, forced to defend their interests at all times.

\section{KEYWORDS}

mining; metallurgy; lead; republic times; rome; hispania ulterior; economy; army 
INTRODUCCIÓN

Si Estrabón hablaba de montañas metalíferas al $\mathrm{N}$ del Baetis -en más que probable alusión a Sierra Morena- (Estr. 3, 142 y 146), otro autor, Diodoro, decía -a propósito de la plata- que los romanos, cuando se impusieron en la Península Ibérica "atestaron las minas y obtenían inmensas riquezas por su afán de lucro". Excusaba este otro autor a los itálicos, seguramente por la codicia que deberían haber demostrado advirtiendo de que esas minas ya habían sido abiertas por los cartagineses o los propios íberos, que habían aprendido sus "peculiaridades" (Diod. 5, 36-38).

Lo dicho por Estrabón en alusión a la explotación de los filones argentíferos que lo antecedieron no es sino una muestra de la riqueza minera de esta región hispana y del interés que ello debió suscitar en el Estado romano y entre los "empresarios" itálicos, ávidos de lograr redes de negocio en una economía en pleno cambio y desarrollo. La plata era sin duda uno de los más lucrativos de los productos -si no el que más- que acababan rentando al erario público y, precisamente, la Península Ibérica gozaba de excelentes regiones argentíferas, como el territorio de Carthago Nova. Parece claro que una economía monetaria, como lo es la de la República, se hace dependiente de un suministro continuo y en progresión geométrica de este metal, acorde con la exigencia de un Estado en plena expansión, también exponencial.

La plata está detrás del incentivo económico que llevó a la Res Publica a fomentar de un modo u otro el avance de la conquista de Hispania, bien de forma directa, bien a través de arrendamientos. Sin duda, el sistema de explotación es uno de los temas más interesantes y que más controversia ha generado en los estudios sobre la minería romana. Por otro lado, la fecha del inicio o cambio de régimen de explotación es aún un aspecto muy discutido, presente aún en el debate historiográfico reciente (Frank, 1933a; 1933b; 1973; Gabba, 1954; Blázquez Martínez, 1970; Badian, 1972; Broughton, 1974; Richardson, 1976; Nicolet, 1979; Blázquez Martínez, 1989; 1996; Mangas y Orejas, 1999; Ñaco, 2003). No obstante, vamos a ir comprobando -a través de los datos arqueológicos de nuestro ámbito de estudiocómo las fechas insisten en momentos avanzados del siglo II a.n.e. para situar ese momento de arranque o intensificación, inmediato en todo caso a ese incremento por la preocupación militar en la zona. Dejaremos para el final de este estudio la derivada de estas ideas como parte de la reflexión; hasta entonces, proseguiremos con el interés metalífero general.

La minería y metalurgia de la plata va íntimamente ligada a la del plomo. Ésta es una realidad que escapa a la forma misma en que solemos encontrar aquélla en la Naturaleza -como galenas argentíferas, la mayoría de las veces-, llegando a ser este último parte inexcusable en los procesos químicos y físicos para producir la ansiada plata. También repasaremos más adelante esta cuestión de la técnica productiva. Entre tanto, me gustaría comenzar a fijar mi posición acerca del papel real que este otro metal -el plomo- tuvo en toda esta febril actividad minera durante la República romana.

$\mathrm{Y}$ es que subsiste la idea de que el plomo se trata de un subproducto, un elemento residual en los procesos argénteos, e incluso un objetivo secundario en una actividad que busca absolutamente la plata. Sin más argumento que la -aún infundada- suposición de que en un lugar determinado se explote el plomo y no la plata, se ha llegado a postergar la minería argentífera de ese lugar hasta la etapa altoimperial (Hernández et alii, 1989, 135). En casos como éste -y he puesto como ejemplo lo expresado a propósito de un enclave republicano tan relevante como Villasviejas del Tamuja (Botija-Plasenzuela) y los ricos filones inmediatos- podemos esgrimir dos razones para relativizar estos postulados apriorísticos. De un lado, no está claro que el plomo sea en exclusividad el objeto de la explotación de sus galenas, pues hemos podido verificar la más que significativa presencia de plata en las escorias de sus residuos de fundición, demostrando la búsqueda de este otro metal aquí (González y Heras, 2010, 902-903). Y por otro, no encontramos razones objetivas para suponer que la extracción del plomo, como producto, sea algo necesariamente posterior a la República -momento de máximo auge del sitiodestinada a cubrir esencialmente la demanda de las ciudades imperiales.

El plomo se emplea, efectivamente, en las conducciones hidráulicas o en la construcción de los edificios públicos y privados, en Hispania o en la lejana Italia, y no debe extrañarnos en modo alguno la exportación de sus lingotes hacia ese destino geográfico y funcional (Beltrán, 1947, 202-208; Domergue, 1965; 1966; 1990, 327). Sin embargo, tenemos que tener en cuenta además que sus posibilidades de aleación son muy valoradas para según qué tipo de utilidad. Recordemos a Plinio (Nat. Hist. 34, 95, 2) cuando hablaba del plomo 
hispano empleado en la obtención del aes o "cobre campano", un metal resultante muy apreciado por su versatilidad en la fabricación de tuberías y otros objetos de "bronce".

Dicho todo esto, cabe sopesar la producción del plomo quizás no con entidad propia ni tan definitoria como la de la plata, pero sí muy relevante e interesante ya incluso en el último cuarto del siglo II a.n.e., cuando parece haber arrancado con decisión toda esa actividad extractiva minera en el lejano occidente hispano. En algunos sectores de esta gran región, también la historiografía ha tratado de relativizar la importancia de la minería en época romana, aunque cada vez son más las voces y los argumentos para sostener esa presencia -casi absoluta- de agentes romanos en los filones argentíferos de Extremadura. Los fósiles-guía más aceptados en este sentido -como las ánforas vinarias republicanas o la vajilla de mesa y cocina itálicas- pueblan esos filones, apareciendo en las escombreras de las galerías y en los grandes escoriales próximos. Ya C. Domergue (1987), en función de estos datos, se preocupó por catalogar y hacer un diagnóstico de toda esa evidencia; señaló cierta concentración de minas y fundiciones en determinadas áreas: Azuaga, en el SE de la provincia de Badajoz, a continuación de los campos filonianos del $\mathrm{N}$ cordobés, y también las comarcas de La Serena y La Siberia, en las tierras altas del Guadiana extremeño.

Baste recorrer algunas de las explotaciones mineras de la industrialización reciente de la región -siglos XIX y XX-para apreciar signos materiales de actividad romana, más sobresaliente en aquellos afloramientos rocosos que una vez acompañaron a los metales en su ascenso a la superficie. Las técnicas más avanzadas de prospección y de extracción de época contemporánea hicieron posible llegar a los filones ocultos bajo los sedimentos terciarios o cuaternarios y volver sobre las viejas explotaciones romanas. También las mejoras en los métodos de lavado y fundición lograrán recuperar metal de escombreras y escoriales, aspectos documentados en más de una ocasión en nuestro ámbito de estudio (González y Heras, 2010, 884-885). No parece pues nada infructuoso rastrear las innumerables minas abandonadas a lo largo del siglo pasado; quizás sólo así apreciaremos la dimensión de la elevada presión romana sobre todos esos filones. Sirva hasta entonces, acaso, valorar el stock de plata y plomo del subsuelo de estas áreas para aproximarnos -tal vez aún muy relativamente- a la realidad antigua.
De tomar en consideración todo lo anterior, tenemos que ser conscientes de la enorme producción de plomo de Azuaga, por ejemplo, donde se explotaban unas galenas con escaso contenido en plata, pero con unas leyes de hasta el $40 \%$ de plomo. Algunas de las minas más importantes, como Joaquina o El Triunfo, son testimonio fiel de su explotación en época romana; esta última, con materiales de cronología republicana (Domergue, 1987, 18). Las grandes empresas del sector, como la "Compañía de Águilas", la "Sociedad Hispalense", "La Amistad" o la "Sociedad Minero-metalúrgica de Peñarroya" se sucedieron y compitieron por el control de la que fuera la "capital europea -si no mundial- del plomo" entre fines del siglo XIX y comienzos del XX.

Castuera o Garlitos, dos poblaciones en la zona oriental de la provincia de Badajoz, podrían ser la referencia de otros de esos centros mineros del momento. El primero se encuentra en La Serena, con más de 50 explotaciones subterráneas, como las del Grupo Miraflores, La Gamonita, La Alondra, El Prodigio, El Triunfo-Nueva Estrella, Rebelde Julia, etc. Y, el segundo -La Siberia-, también con densidades muy importantes, concentra los filones de Cabeza del Buey, Peñalsordo o Zarza Capilla, con los grupos mineros de Las Trescientas o El Borracho. Las Minitas, en Garlitos, supone además uno de los más interesantes ejemplos de ocupación romana, republicana y seguramente también militar.

En este estudio se ha querido plasmar toda esa realidad geológica, minera, arqueológica y territorial, tratando de alcanzar un objetivo eminentemente histórico. Para ello, tomamos la referencia de estas áreas o comarcas comprendidas entre la línea del Guadiana -su tramo medio- y la falda norte de Sierra Morena (fig. 1), insertando en ellas las explotaciones operativas durante el periodo romanorrepublicano, poniendo de relieve su relación con la producción del plomo y revisando las posibilidades cronológicas que ofrecen los materiales, eminentemente la moneda.

\section{Algunos APUNTES tÉCNICOS}

De alguna forma, a lo largo de estos párrafos introductorios he tratado de esbozar algunas de las líneas de trabajo que pretendo desarrollar en lo que sigue. Partiré de una realidad geológica de la que no puede escapar ni la dimensión ni la tecnología de la minería romana. Continuaré con un sucinto repaso por la realidad arqueológica -geográfica, material y cronológica- de las minas y fundiciones, im- 


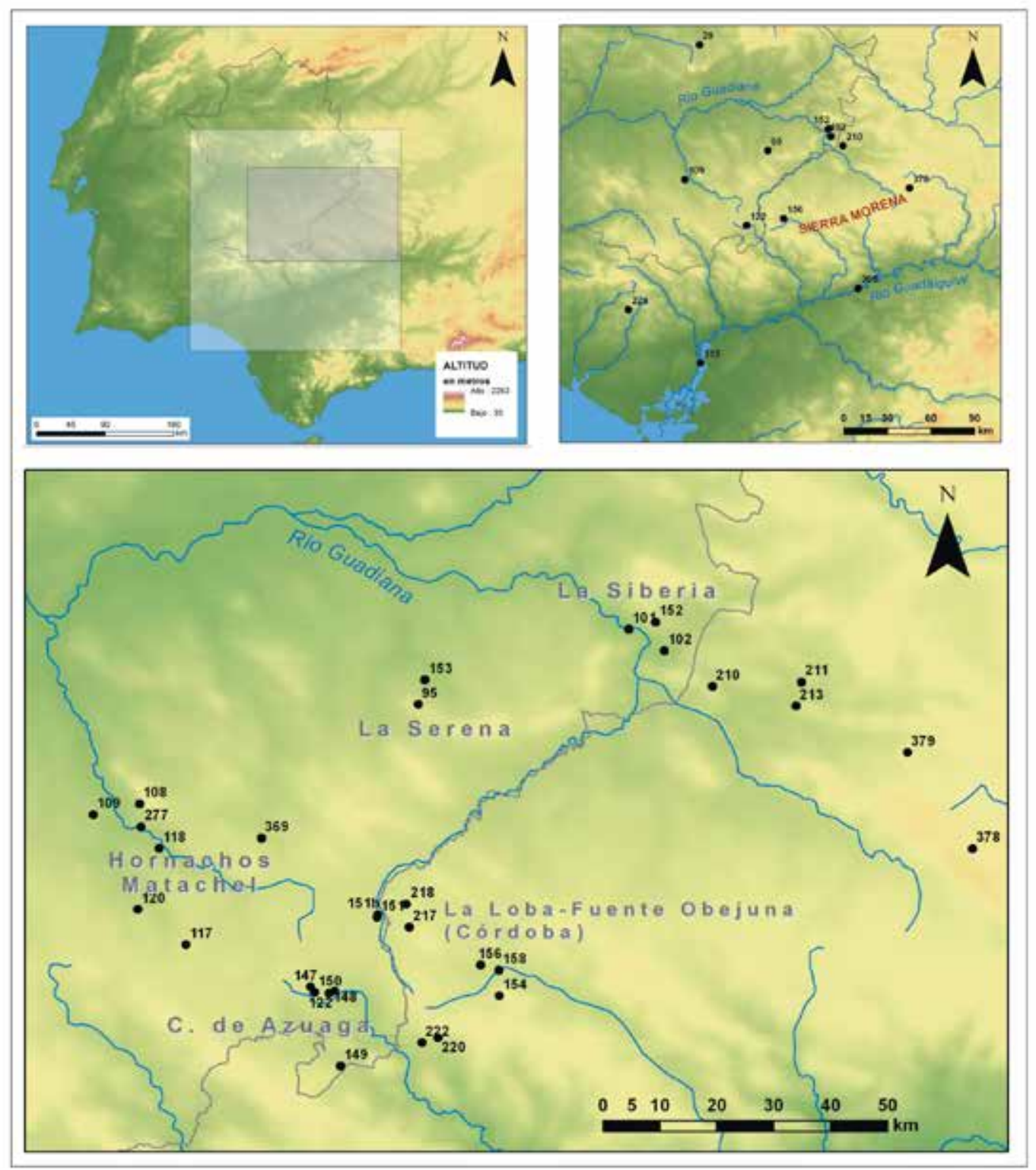

Figura 1. Mapa de situación y general del ámbito territorial del estudio.

bricadas en aquel "paisaje geológico" del extremo noroccidental de Sierra Morena. La reflexión final tendrá que ver con la inserción de todo ello en su contexto espacial e histórico. Se trata, en definitiva, de valorar la producción del plomo en los primeros tiempos del periodo romano en el SO peninsular, su papel y relevancia para la expansiva economía romana de la República.

Antes de proseguir con la exposición de los datos y su interpretación histórica es necesario recabar algunos detalles geológicos que permitan la otra contextualización, la de los recursos naturales, su geografía y disposición. Qué duda cabe que la for- ma en que los minerales aparecen en la Naturaleza condiciona en buena medida la dimensión espacial y entidad de las explotaciones, también la evidencia que deja sobre el terreno, o los requerimientos técnicos y tecnológicos para su extracción o sintetizado. No deseo, en cambio, hacer aquí un análisis exhaustivo de los procesos físicos y químicos presentes en la producción metalífera antigua, acaso sí un repaso -aún somero- de aquellas particularidades de los minerales, de los metales y sus aleaciones que nos ayuden a conocer e interpretar la realidad que encontramos. 


\subsection{Geología}

Desde el punto de vista geológico, la mitad meridional de la región extremeña comprende un espacio heterogéneo, a caballo entre dos importantes zonas metalogenéticas: la Zona Centro-Ibérica y la Zona de Ossa Morena. Entre ambas se contempla una franja de fracturas, la llamada Banda de Cizalla Badajoz-Córdoba, que marca una tendencia de orientación NO-SE para los relieves (elevaciones y depresiones o hundimientos) y donde cabe encajar el Batolito de los Pedroches o la Falla de Azuaga (VV. AA, 1993, 19). Centrándonos en la primera de las zonas, ámbito geológico esencial de nuestro estudio, cabe señalar la primacía del Complejo Esquisto-grauváquico o Alcudiense, "salpicado" de afloramientos plutónicos como el Batolito de Extremadura Central o el aludido de Los Pedroches, que generan en su perímetro nuevas regiones de fractura.

En este complejo panorama geológico, donde no faltan placeres -oro- en los lechos de los ríos o algunas masas ferruginosas o polimetálicas, destaca la importante supremacía de los sistemas filonianos. Una parte más que notable de los recursos metalíferos de la región se encuentra en forma de filones, entre los que abundan sobre todo las mineralizaciones del tipo plomo-zinc-cobre o "galena-zincblenda”. Los compuestos argentíferos, por su parte, contarán a lo largo de la historia con una mayor atención sobre todo por su peso económico. En este sentido, los campos filonianos resultantes de las fracturas periplutónicas de Plasenzuela o las bandas de cizalla de Montánchez, también aquella de Badajoz-Córdoba, han marcado tradicionalmente esa geografía de la minería de la plata y el plomo. Minas como La Sevillana, Golondrinas, Serafina o Los Palacios son algunos de los más significativos ejemplos de explotación decimonónica de los filones argentíferos del área cacereña con manifiestas señales de un laboreo romano de cierta envergadura.

Ya en el ámbito del Guadiana medio, a partir de las fracturas en torno a la Falla de Azuaga -encajadas en la formación del mismo nombre- resulta el otro gran sistema filoniano del S extremeño, con paragénesis -esta vez- de esfalerita, galena, calcopirita, pirita y tetraedrita ocasional, o también los de los "Gneises de Azuaga", enriquecidos en cobre (VV. AA., 1993, 184; 2007, 64-65, 71). En las comarcas de La Serena y La Siberia, los filones -fundamentalmente de cuarzo, también carbonatos (dolomitas, ankeritas y calcitas)- se han formado en las grietas del Complejo Esquisto-grauváquico, dando lugar a paragénesis metálicas similares a las anteriores, sobre todo galena argentífera, también esfalerita, pirita, calcopirita y minerales supergénicos procedentes de las anteriores (VV. AA., 1993, 182; VV. AA., 2007, 157-161). En el centro mismo de la provincia de Badajoz se encuentra otro de esos sistemas de filones, brechas metálicas de pequeño tamaño en torno a la formación terciaria de la Sierra Grande de Hornachos y del río Matachel; de nuevo aquí se explotarán masivamente durante época reciente y también romana las galenas argentíferas, hoy sin interés económico (VV. AA., 1993, 185).

Toda esta dimensión espacial de la geología extremeña va a condicionar -como tendremos ocasión de comprobar- esa geografía de los recursos mineros. Quizás sea en función de ésta como habremos de entender ese otro mapa, el de la conquista romana del territorio, para el cual estableceremos al menos cuatro áreas dentro de la provincia de Badajoz, aún próximas y probablemente interconectadas en cuanto a su explotación: Azuaga, Hornachos, La Serena y La Siberia.

\subsection{Tecnología}

Uno de los principales aspectos que debemos de tener en cuenta, a la luz de los datos arqueológicos con los que contamos para el tiempo de la República Romana en Extremadura, es pues el carácter filoniano de la explotación minera y su enfoque -al menos a priori- hacia el beneficio de esas galenas. Como adelantaba líneas atrás, es la presencia del mineral en forma de filones -mayoritariamente subverticales- lo que condiciona el tipo de minería que vamos a documentar en esta parte al $\mathrm{N}$ de Sierra Morena. Es frecuente la constatación de trincheras abiertas en la roca que ponen de manifiesto el vaciado del filón, aunque no falta en modo alguno el acceso a éste mediante pozos y galerías, entre cuyas escombreras se distinguen restos cerámicos que ratifican su explotación durante época romana. Con todo, la más habitual de las huellas de laboreo antiguo registrado en la región obedece a esas estrechas excavaciones en la piedra de base que pueden alcanzar sin embargo muchos metros de profundidad.

Además de aquel rastro "en negativo", las terreras a ambos márgenes de las rafas mineras constituyen muchas veces auténticas lomas artificiales, difuminadas por el paso de los siglos y con frecuencia pobladas de vegetación que las camufla aún más. A 
pesar de ello, encontramos en ellas los fragmentos cerámicos -constructivos y vasculares- que posibilitan adscribir el laboreo a una época histórica u otra. Casi siempre son restos de tegulae los que aparecen en el entorno más inmediato, pero no resultan del todo infrecuentes los taxones anfóricos que marcan cierta actividad durante el periodo romanorrepublicano. Las ánforas Dr. 1A son casi una constante, como tendremos la ocasión de comprobar.

Veremos más adelante cuáles son esas minas preimperiales y si guardan alguna relación con una explotación algo más reciente; también si a parte de este primer estadio extractivo podemos rastrear otras tareas derivadas en el mismo entorno de la mina. Por el momento baste con incidir en la dificultad para detectar otros procesos necesarios que, sin excavaciones sistemáticas en todo el ámbito regional, no alcanzamos a conocer; es el caso de la trituración y del posterior tostado del mineral. No ocurre lo mismo, sin embargo, con el procedimiento de fundición que, aunque no se trate en realidad de una actividad a bocamina, en gran parte de las ocasiones se realizaría en las inmediaciones. Las escorias de fundición constituyen en este sentido el más claro indicio de localización de este proceso. Su presencia marca la proximidad de los hornos de reducción, de forma aún más contundente los grandes escoriales que llegan a conformar auténticos cerros artificiales en algunos casos. No han faltado tampoco iniciativas en tiempos recientes que han pretendido -y acometido en muchos casos- la explotación de los mismos residuos romanos, aprovechando las mejoras tecnológicas de la industrialización contemporánea o basándose en la apreciación económica de los metales durante el siglo XIX o XX. Sabemos de ejemplos de ello en La Serena, e incluso podemos recordar la aventura empresarial incitada por el ingeniero Clemente Roswag en los grandes escoriales romanos inmediatos a Villasviejas del Tamuja (Botija, Cáceres), referencia en la arqueología romanorrepublicana en Extremadura (González y Heras, 2010).

$\mathrm{Si}$, en cierta medida, abundan las acumulaciones de escorias como prueba de la reducción de los minerales, cuestión bien distinta es la propia evidencia de los hornos en que ésta tuvo lugar. Apenas sí conocemos algún ejemplo de estructura metalúrgica, no obstante, sin que esté del todo claro si se trata de hornos de fundición o si, en cambio, están destinados al calentamiento para la forja o manipulación del metal. Por otro lado, aún resulta determinante establecer alguna relación entre los hornos conoci- dos y los poblados amurallados de la región (Enríquez y Rodríguez, 1988, 126; Rodríguez, 1991, 39, fig. 12; Berrocal 1992, 177, 179; Alvarado, 1994, 17; Ortiz y Rodríguez, 1998, 260). En realidad, este apriorismo debe ser consecuencia del hecho de que las actuaciones arqueológicas se hayan ceñido tradicionalmente a los hábitats y necrópolis, y no a los ambientes productivos de su entorno. Así y con todo, subsisten lagunas en cuanto a la cronología real de estos elementos. En más de una ocasión se han datado en época prerromana, esgrimiéndose para ello una posición estratigráfica acorde con los niveles anteriores a la presencia romana en los hábitats. Quizás habremos de revisar tal consideración y plantearnos si no se trata en realidad de substructuras cavadas bajo los suelos tardíos -seguramente ya republicanos- e insertas por tanto en los niveles protohistóricos. De hecho, en más de una ocasión estas huellas de combustión intensa pueden fácilmente encuadrarse en momentos próximos al fin del hábitat; incluso forman parte de ese postrero nivel de amortización que anula los mismos sistemas defensivos prerromanos.

Volvamos a los residuos de fundición y las posibilidades que ofrece su localización y análisis. Las escorias que encontramos en los ambientes romanorrepublicanos de la zona obedecen en su mayoría a aquella geografía de la plata y el plomo. No faltan algunos indicios de metalurgia asociados a otras mineralizaciones distintas a las argentíferas -como el cobre e incluso el estaño-, aunque en el cómputo general resulten de escasa relevancia cuantitativa y, quizás, poco significativos, pues pueden relacionarse con fases anteriores. Lamentablemente, son por el momento también escasas las muestras analizadas -o, cuanto menos, las dadas a conocer- que puedan ayudarnos a determinar y detallar las producciones, a través de la presencia de los distintos elementos o la tecnología empleada (p. ej.: Domergue, 1987, 212 -análisis n⿳0 71-; González y Heras, 2010, 902-903, fig. 9).

Hemos de tener en cuenta, aún a propósito de la fundición, ciertos aspectos químicos esenciales para alcanzar el éxito en la obtención de ese "plomo argentífero”. En los hornos en que tendría lugar la reducción del mineral se combina éste y el fundente. Por otro lado, determinadas mineralizaciones pueden requerir otras adiciones, como un suplemento extra de plomo en el caso de la jarosita, a fin de despejar la plata del resto del compuesto en el horno (Blanco et alii, 1970, 157; Hunt, 1988, 147; Pérez, 
1991, 102; Pérez y Delgado, 2007b, 289). Este último procedimiento alcanza una importancia capital, al menos para nuestra futura interpretación histórica, pues la demanda de plomo en mineralizaciones deficitarias en este mineral puede condicionar los intereses y las relaciones entre las áreas o espacios mineros, fundamentadas en redes comerciales o empresariales. El caso de la cuenca de Riotinto -por ejemplo- resulta especialmente esclarecedor, puesto que su valor como gran productora de plata durante el periodo romano debió estar supeditado en buena medida al suministro regular de lingotes de plomo del exterior (Domergue, 1990, 56-58; Domergue y Rico, 2014, 155). Las "regiones argentíferas" de Carthago Nova y de gran parte de Sierra Morena -también central y occidental- habrían de desempeñar un papel clave en estos circuitos, en tanto que de sus procesos metalúrgicos se obtiene un destacado "sobrante" de plomo.

Este último no es sino el resultado de otro de esos procesos: la copelación. Es una de las cuestiones tecnológicas más importantes que habría que reseñar, y tiene que ver con el procedimiento físico para lograr individualizar los metales a partir de las amalgamas obtenidas tras la reducción. Se fundamenta en la diferencia del punto de fusión de la plata y el plomo -el de éste se alcanza con menor temperatura- y persigue la separación de uno y otro elemento, en el interior de una "copela", a partir del régulo de plomo argentífero resultante de la reducción del mineral (Blanco y Rothemberg, 1981, 311; Fernández Jurado, 1993, 146; Fernández Jurado y Ruiz Mata, 1995; Rovira, 1995, 486; Pérez, 1995; Pérez y Frías, 1989; Domergue, 1990, 506; Izquierdo, 1997, 89-91; Hunt, 1995; 2000, 163-164). Si bien esta técnica de la copelación es conocida y empleada ya en época tartésica, lo cierto es que debió ser durante el periodo romano cuando alcanzó mayor relieve, siendo tal vez responsable de la producción argéntea que atrajo la inversión de Roma hacia estos territorios occidentales.

También podemos relacionar con el aspecto tecnológico las aleaciones funcionales. Éstas están estrechamente relacionadas con el uso a que va destinado tal o cual metal. Tomaremos como ejemplo ese "aes campano" a que me refería al comienzo de este trabajo. El cobre, amalgamado con estaño nos lleva a un compuesto conocido siglos atrás, empleado con frecuencia en la fabricación de hachas y espadas durante la Edad del Bronce. Sin embargo, también el cobre puede combinarse con el plomo y lograr ese apreciado aes, más versátil o dúctil, con que se fabricarán conducciones y utensilios durante el periodo romano (Plin., Nat. Hist. 34, 95, 2).

\section{MiNAS Y FUNDICIONES EN EL ÁMBITO EXTREMEÑO:} ÁREAS GEOGRÁFICAS DE ESTUDIO

Con todo lo que se ha dicho hasta ahora, en vista a las dimensiones alcanzadas por la explotación argentífera extremeña, derivada de los recursos que guardaba el subsuelo, y con la muestra recogida por C. Domergue -en su "Catalogo de minas y fundiciones" de 1987-, puede llegar a sorprendernos el hecho de que todavía no hayamos sido capaces de acometer un estudio decidido sobre la minería antigua en la región. Es fundamental iniciar ese camino, concretamente para el periodo romano, donde los datos siguen estando muy dispersos, aún faltos de ordenamiento cronológico y -como vengo defendiendo- con tendencia a minimizarse. No obstante, hemos de tener en cuenta algunos pequeños estudios que, con mayor o menor fortuna, vinieron a suponer los primeros balbuceos en este sentido.

La serie de pequeños trabajos del profesor Fernández Corrales apuntaban ya esa tendencia a la relativización de la minería romana frente a lo que estaba ocurriendo en otras regiones limítrofes durante la misma etapa romana (Fernández Corrales, 1987; 1988; 1989). Los estudios sobre el hierro del Ardila también resultan muy interesantes para contextualizar ciertas evidencias materiales, como los hornos de Capote o de Castillejos de Fuente de Cantos, entre otras (Rodríguez, 1991, 39, fig. 12; Berrocal, 1992, 177, 179; Alvarado, 1994, 17; Paniego, 2014). Sin embargo, un modesto artículo de Jiménez Ávila (1989-90) va a ser tal vez uno de los que, sin afán sintético alguno, logre poner el acento sobre la producción metalífera republicana en la región y atraer hacia aquí la atención de los investigadores.

\subsection{Hornachos-Valle del Matachel}

Este trabajo al que me refiero se tituló "Notas sobre la minería romano-republicana bajoextremeña: las explotaciones de plomo de la Sierra de Hornachos (Badajoz)", y con él pretendía introducir algunas cuestiones históricas en el análisis de uno de los sitios arqueológicos más interesantes de la etapa romanorrepublicana en Extremadura: Hornachuelos. Tomaba como argumento central el hallazgo de un lingote de plomo en el Cerro de las Cruces (fig. 2), a las afueras de la población pacense de Hornachos, a unos $10 \mathrm{~km}$ al noreste de aquel otro. Ilustra- 
ba su argumentación con otros objetos metálicos, como unas "téseras", pesas de plomo y proyectiles de honda, procedentes del entorno de Hornachuelos (Jiménez, 1989-90, 130-133, figs. 3 y 4).

El lingote supone una pieza de excepcional valor histórico, ya no sólo porque nos permita abundar en la producción plúmbea de este lugar, en cuya superficie aún se pueden encontrar fragmentos de ánforas vinarias itálicas del tipo Dr. 1A entre las escombreras y escoriales metalúrgicos del Cerro de las Cruces. El verdadero interés del hallazgo es sin embargo la cartela epigráfica que presenta y las posibilidades de lectura e interpretación que permite. Antes de proseguir, tomemos en consideración el vecino enclave romano de Hornachuelos, su raíz etimológica y la probable cercanía geográfica de la mansio denominada Fornacis, que menciona Ptolomeo $(2,4,10)$. La ecuación no podría resultar más sugerente: Fornacis $=$ Hornachos/Hornachuelos, defendida por los excavadores de este sitio (Rodríguez y Jiménez, 1990, 19-23; Rodríguez, 1992, 291; Rodríguez y Enríquez, 2001, 305; Ortiz y Rodríguez, 1998, 260). Ahora sí, en la inscripción del lingote rezaban las siglas S.F.B., y la lectura que hace J. Jiménez es S[ocietas] F[ornacensis] $B$ [aetica] (Jiménez, 1989-90, 127). Si bien es cierto que pueden argüirse alternativas a esta propuesta de transcripción, lo que parece no mostrar dudas es la pertenencia de este objeto a una industria relacionada con el plomo. Tal vez se trate efectivamente un centro destinado a la fundición, aglutinador de la producción minera de multitud de filones explotados en los alrededores en fecha romanorrepublicana, y donde el topónimo mismo estaría poniendo el acento en la abundancia o relevancia de "hornos" en el sitio.
Por su parte, el sitio de Hornachuelos constituye un verdadero hito paisajístico de la cuenca media del río Matachel, afluente de la margen izquierda del Guadiana. Su perfil quebrado y apuntado sobresale de la pauta ondulada de las tierras al S de la Sierra Grande de Hornachos. Hoy sabemos que parte de su silueta escalonada se debe a la acción antrópica, con terraplenes en la ladera ocultando una o más líneas de muralla que encierran un espacio interior urbanizado, con calles y construcciones rectangulares que se abren a ésta. La relación de este enclave romano con la minería, como centro capitalizador, administrador de la actividad del entorno, ya ha sido puesto de relieve en diversas ocasiones (Rodríguez, 1992; Rodríguez y Jiménez, 1990; Ortiz y Rodríguez, 1998, 260; Rodríguez y Enríquez, 2001, 305). Ya incluso como resultado de las excavaciones en su interior se han documentado pruebas directas de ello, como la aparición de escorias, un yunque, una maza, un posible crisol, lingotes, pesas y un horno (Ortiz y Rodríguez, 1998, 260; Rodríguez, 1992, 291). Tanto la estratigrafía, como los materiales cerámicos o el conjunto monetario asociado a este sitio nos llevan directamente a considerar varias fases en la vida del centro, siendo de especial interés la etapa republicana (Rodríguez y Jiménez, 1990a, 27; Jiménez, 1990b, 18; Rodríguez, 1992, 291).

Además de la explotación metalúrgica derivada de los restos republicanos del Cerro de las Cruces o del propio enclave fortificado de Hornachuelos, el entorno inmediato de este último se encuentra jalonado de otras evidencias de excavación de filones. Sitios como el Cerro de la Matilla, por ejemplo, aparecen horadados por extensas trincheras, en cuyos márgenes se acumulan los escombros extraídos de

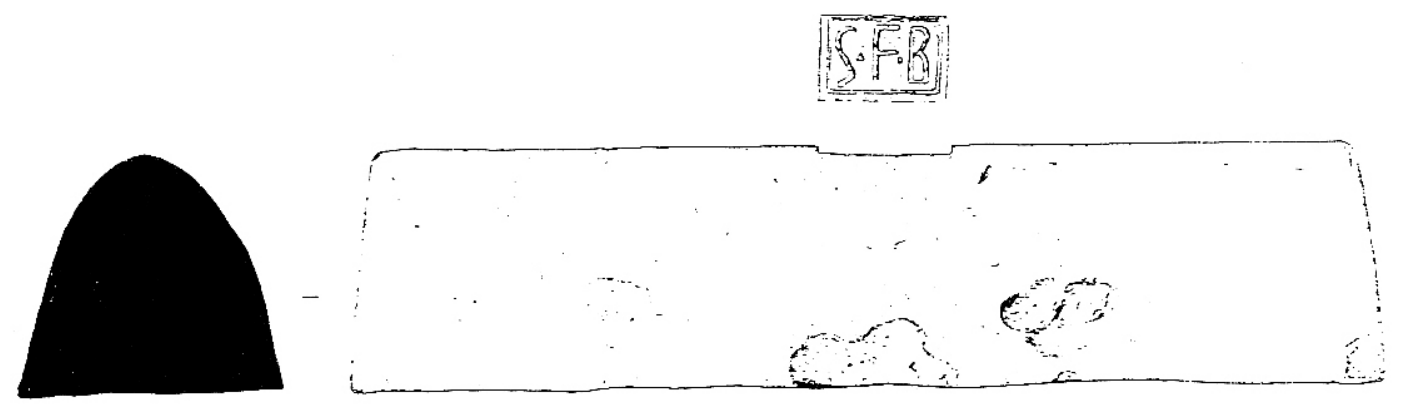

Figura 2. Dibujo del lingote de plomo aparecido en el Cerro de las Cruces, a las afueras de la localidad de Hornachos (Jiménez, 1989-90, fig. 1). 
su interior (Domergue, 1987, 40). Entre éstos y, sobre todo, en las laderas del cerro podemos encontrar abundantes escorias y fragmentos de ánforas itálicas, de pastas con inclusiones volcánicas. También existen indicios mineros y de metalurgia antiguas -pozos, rafas y escorias- en las explotaciones recientes de La Trasierra o en otros puntos de la Sierra de Hornachos, como el Camino de los Cristianos.

El ámbito espacial que se comienza a perfilar en torno a este centro de Hornachuelos se hace más complejo si tenemos en cuenta una serie de peñones o establecimientos "fortificados", como El Castillejo de Ribera del Fresno, Los Peñones o El Peñón de la Mora, que -en conjunto- pudieran tener una misión defensiva (Rodríguez, 1987, 190, 537; Jiménez, 1990a, 343, 346). No obstante, este tramo superior del valle del Matachel es si cabe más interesante que todo esto, debiendo incluir tal vez las referencias, con ocupaciones republicanas, de El Cabril de Llera, el Peñón del Moro de Villagarcía de la Torre o El Donadío, ya no demasiado lejos de La Dehesilla, un enclave protohistórico con ocupación romana temprana y vecino a la comarca de Azuaga (Rodríguez, 1995, 235-236; Rodríguez e Iniesta, 1984).

\subsection{La Serena, la Siberia y Almadén}

Las explotaciones de plomo de la comarca pacense de La Serena han sido, entre finales del siglo XIX y comienzos del XX, un hito muy importante en la minería nacional. Aún hoy persisten los esqueletos de las imponentes construcciones industriales decimonónicas, como los castilletes de fábrica y las ruinas de las demás instalaciones, ya muy desdibujadas. La compañía "Fundición de Plomo de La Serena" se había encargado de la explotación de los ricos filones argentíferos. Hoy, rastreando los residuos de toda esta actividad, aún son perceptibles taxones cerámicos que denuncian labores mucho más antiguas. También para esta zona, C. Domergue puso de manifiesto esa presencia romana en las minas y fundiciones del área de Castuera (Domergue, 1987, 29-31); en algunas de ellas, esas evidencias son ya de época republicana, como los restos de ánforas procedentes del entorno napolitano reconocidas en La Gamonita o Antoñita.

También proceden de la zona -Castuera (Jiménez, 1989-90, 126), en el corazón de La Serena- algunos sellos de plomo con las iniciales S.BA. del Museo de Badajoz ${ }^{1} n^{\circ}$ inv. 11959, 11960, 11969) (fig.

1 Agradezco sinceramente la amabilidad y facilidades

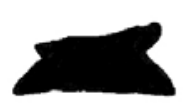

1

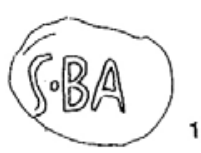

1
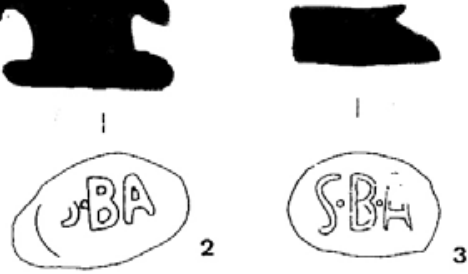

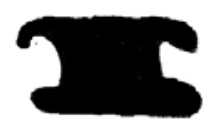

Figura 3. Dibujo de tres precintos de plomo del Museo Arqueológico de Badajoz (Col. Calzadilla y de una mina de Castuera), con la leyenda S.BA.; según Jiménez 198990, fig. 2.

3), que en El Centenillo (Jaén) el propio Domergue puso en relación con la producción minera republicana del sitio (Domergue, 1971). También en las minas de Santa Bárbara, cerca de Azuaga y de Fuente Obejuna (Córdoba), podría volver a documentarse la participación de esa misma societas, a partir de un nuevo precinto de plomo que leyó como $S$ (ocietas) B(aetica) o Ba(edronensis) (Domergue, 1971, 350, 352; 1987, 137-138, lám. XLI b-4; Arévalo, 1996, 62; Casariego, Cores y Pliego, 1987, 31, 32); una lectura distinta: A(rgenti fodinarum) (Blázquez Martínez, 1996, 187; Mangas y Orejas, 1999, 251). No me resisto, acaso, a especular sobre la posibilidad de que sea aquella otra S[ocietas] F(odinarum) B(aedronensis) del lingote de Hornachos, aunque -como digo- sea en realidad sólo eso, un ejercicio de pura especulación.

Volviendo a la objetividad de la prueba material, hacia el E de la extensa comarca de La Serena se abren las agrestes tierras de La Siberia, marcada por el encajonamiento del río Guadiana, después de descender de la Meseta castellano-manchega, y por las Sierras de Siruela o Los Montes. También en época reciente se instalaron industrias para la extracción de plata y plomo en los filones de Cabeza del Buey, Peñalsordo, Capilla, Zarza Capilla o Garlitos (fig. 4).

Desde el punto de vista arqueológico, en el centro de todo este territorio encontramos alguno de los más interesantes ejemplos de implantación romana, con una posible relación con los recursos mineros de la zona (Pastor et alii, 1992, 88); me refiero al Cerro del Cabezo, cuyos restos fueron identificados con la Mirobriga de Plinio (Nat. Hist. 3, 13-14), Ptolomeo (2, 4, 10) o el Itinerario

del Museo Arqueológico Provincial de Badajoz para acceder a esta información, la voluntad demostrada por su director, G. Kurtz, y la desinteresada disponibilidad de sus conservadores, B. Griñó y A. Silva. 
de Antonino $(444,6)$ por sus excavadores (Pastor et alii, 1992). Su arranque es sin duda republicano, con materiales que así lo parecen demostrar, aunque la prudencia nos lleva cuanto menos a señalar a un momento avanzado para el proyecto urbano que conocemos.

El contrapunto a esta supuesta fundación "tardía” es el enclave de las Tablas de las Cañas - también en el término municipal de Capilla-, que vendría a significar aquel hábitat prerromano con indicios de ocupación republicana, no obstante próxima a su abandono (Domínguez y García, 1992, 236; Chico y Rubio, 1982). Entre estos niveles finales volvemos a documentar escorias, posibles indicios de metalurgia en un entorno con unos atractivos recursos argentíferos; por ejemplo, las explotaciones de El Borracho y Las Trescientas.

Con todo, el panorama de la explotación minera romanorrepublicana se hace más interesante cuan- do incorporamos la información que nos permite el enclave de La Minilla de Garlitos. Ubicada al pie de la Sierra de la Minerva, supone hoy un entorno jalonado de pozos antiguos y recientes, todos ellos abandonados. Es también una suave plataforma en cuya superficie se han hallado indicios de ocupación de esta cronología, de signo minero-metalúrgico y militar, seguramente interrelacionados. Se trata de ánforas, lucernas, proyectiles de honda y ponderales de plomo, muy presentes en el habitual registro de las minas antiguas. Las monedas de Obulco, Castulo, Sekaisa, Aratikos, Arekoratas y Bolscan, junto a la tipología de las ánforas -reconocibles las Dr. 1A- refuerzan ese momento para la explotación de los filones (Domergue, 1987, 37, fig. 39-A; Tejada, 1997, 49-50, fig. s/n).

La proyección natural de estas comarcas orientales de la provincia de Badajoz nos lleva a remontar unos kilómetros el valle del Guadiana y aden-

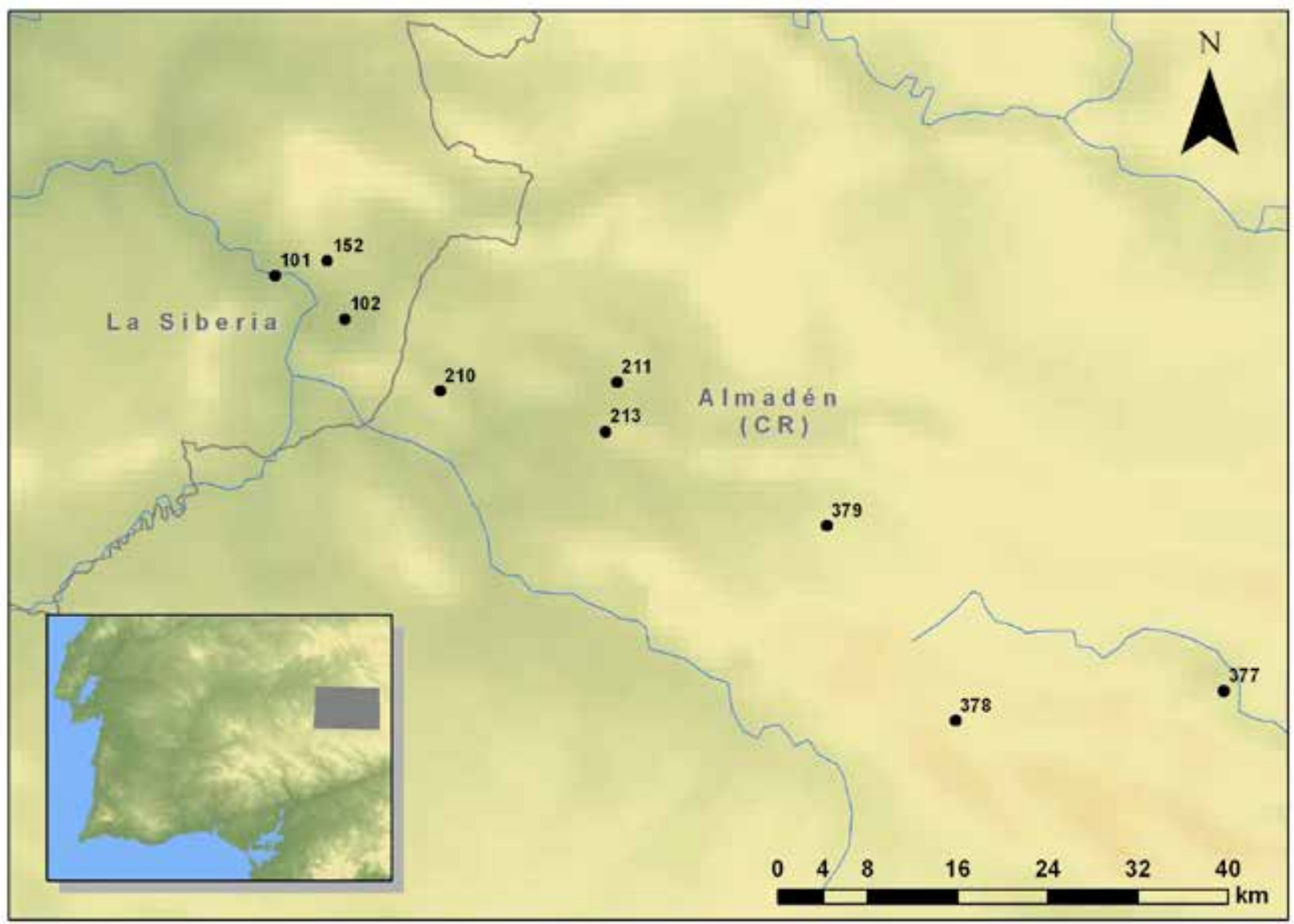

Figura 4. Mapa de situación de los indicios mineros de la comarca extremeña de La Siberia y de Almadén (Ciudad Real): $\mathrm{n}^{\mathrm{o}} 101, \mathrm{n}^{\mathrm{o}} 102, \mathrm{n}^{\mathrm{o}} 152, \mathrm{n}^{\mathrm{o}} 210$ Fundición San Pablo (Chillón, CR), $\mathrm{n}^{\mathrm{o}} 211$ Guadalperal (CO), $\mathrm{n}^{\mathrm{o}} 213$ Quinto del Hierro (Chillón, CR), nº 377 Mina Diógenes (CR), nº 378 Valderrepisa (CR), nº 379 La Bienvenida (CR). 
trarnos en la vecina Ciudad Real. Aquí se abre un campo especialmente interesante para la minería antigua. El equipo que estudia el aspecto territorial de Sisapo-La Bienvenida ha venido compilando la información que en este sentido existe en la zona, partiendo de los trabajos de Domergue (1987) y abundando en el conocimiento de campo (Fernández et alii, 2002; Zarzalejos et alii, 2012a; 2012b). Cada vez parece más contundente el hecho de que la explotación de los recursos argentíferos de esta parte de la geografía alcanzara gran importancia en la etapa republicana. No en vano, las minas y fundiciones de Guadalperal (Domergue, 1987, 65; Zarzalejos et alii, 2012a, 71; 2012b, 135), de San Pablo (Domergue 1987, 75-76, fig. 40-A) o Quinto del Hierro (Domergue, 1987, 62-64, fig. 40-C; Fernández et alii, 2002, 66-67; 2003, 262; Zarzalejos et alii, 2012a, 71-72, figs. 7 y 8; 2012b, 145), muestran indicios materiales claros de esta etapa.

No demasiado lejos, Mina Diógenes (Domergue, 1967; 1987, 81-83) conforma uno de los ejemplos más conocidos de la minería de estas comarcas al $\mathrm{N}$ de Sierra Morena y también próximas a ese gran centro protohistórico y romanorrepublicano de $\mathrm{La}$ Bienvenida. Valderrepisa es otra de estas minas republicanas de la región, con ánforas y monedas que marcan la actividad extractiva a partir -con mayor seguridad- de mediados del siglo II y hasta inicios del I a.n.e. (Fernández y García, 1993, 31; Marcos, 1993, 49).

Todos estos enclaves, junto a los anteriores, a uno u otro lado del límite provincial, suponen efectivamente un conjunto coherente de minas y fundiciones dirigidas a la explotación de las galenas argentíferas. Además, son coetáneas, en un momento en que buena parte de Sierra Morena se ve envuelta en una dinámica económica y militar sin precedentes.

\subsection{Azuaga-Fuente Obejuna}

En la divisoria de aguas del Guadiana y el Guadalquivir se encuentra la población pacense de Azuaga. El símbolo histórico es sin duda el Castillo de Miramontes, elevado en lo alto de un promontorio apuntado y aislado, en el extremo meridional de las planicies de la Campiña Sur. Su figura se alza como referente paisajístico en buena parte de estas llanuras, pero sobre todo de los encajonados valles del río Bembézar y sus afluentes, a lo largo de la depresión que anticipa la vertiente norte de Sierra Morena. Geológicamente ya he referido la naturale- za y significado de la Falla de Azuaga -y con ella la propia Banda de Cizalla Badajoz-Córdoba-, como factor orogénico propiciador de un interesante sistema filoniano. Donde han desaparecido los sedimentos terciarios la roca aflora con sus compuestos metálicos y ello sin duda ha sido aprovechado con avidez durante la Antigüedad. Hoy, los restos de las viejas explotaciones mineras decimonónicas de la zona se convierten en elementos omnipresentes en el paisaje; baste sólo prospectar las inmediaciones de aquéllas para comprobar que una parte muy importante ya estaban en uso en tiempos romanos (fig. 5).

El Cerro del Castillo de Miramontes es buena prueba de esa intensidad del laboreo romano. Aún persisten en superficie abundantes escorias de fundición junto a un repertorio cerámico que arranca desde la Prehistoria hasta el Bajo Medioevo. Nos interesa destacar la persistencia de vajilla de barniz negro, ánforas itálicas e incluso monedas que nos sitúan entre los siglos II y I a.n.e. (Domergue, 1970, 622-623, fig. 7.2-7.7; Alonso, 2005). De hecho, el argumento más relevante en este sentido lo conforma el hallazgo de centenares de proyectiles de plomo, algunos de ellos con la leyenda Q.MET. (fig. 6), de lo que Domergue dedujo su pertenencia a Quinto Cecilio Metelo e interpretó como posible stock de munición fabricada aquí para su combate contra Quinto Sertorio (Domergue, 1970, 612-615, figs. 3 y 4 ).

En el entorno más inmediato encontramos las minas y fundiciones de El Triunfo, donde la presencia de ánforas itálicas del tipo Dr. 1 permiten establecer cuanto menos cierta proximidad cronológica respecto a la ocupación del Cerro del Castillo o las minas de Las Musas, al pie de la meseta en que se emplaza el caserío urbano de Azuaga (Domergue, 1987, 17). Tampoco queda lejos -apenas dos kilómetros de éstas y tan sólo uno de aquélla otra- los restos del pozo y rafas de El Carenil, en un pequeño espigón fluvial de la que participa el Arroyo Jituero (Domergue, 1987, 19). Este último caso nos puede resultar especialmente paradigmático si accedemos al fotograma del "vuelo americano" -de 1956-, previo a la reforestación que afectó a amplias extensiones de terreno en la zona. En la fotografía son apreciables con nitidez las labores mineras más recientes, pero también una línea algo más difuminada que remarca el límite del espacio comprendido por esa confluencia de arroyos, y que cierra en recto el extremo contrario. En realidad, parece tratarse de 
un surco en forma de "quilla" de barco, con lados perfectamente simétricos, que define un pequeño recinto (fig. 7). En su interior, entre los escombros del pozo contemporáneo, se han documentado tejas romanas vitrificadas junto a ánforas altoimperiales y republicanas, además de los materiales y escorias de fundición que ya diera a conocer C. Domergue $(1987,19)$.

Lo cierto es que las pruebas de laboreo romano se extienden por decenas de explotaciones de plomo recientes, pero sólo en unas pocas de ellas los materiales nos permiten certificar esa cronología republicana que buscamos y por la que apuesto en más casos de los que en un principio podríamos asegurar. Y es que hay que tener en cuenta que los restos cerámicos en general constituyen una "feliz casualidad" tras revisar recurrentemente las terreras de las minas. Esto es sin duda culpa de la notable alteración de las labores más recientes, que copan una extensión casi siempre mayor que las antiguas y que han movido volúmenes de escombro que en poco tienen que ver con lo que ocurre con la mayoría de las explotaciones romanas. Algunas de esas minas son las de El Triunfo o Las Musas-Plasenzuela o El Revuelo (I y II), aludidas anteriormente, pero también la del Arroyo Téllez, la del Guaditoca, Segunda Pepe, Juno, San José, Carmelita, Escarranchal, San Fernando, Gerty, Infierno, Araceli, San Rafael, Alquitones, Las Morenas, El Lirio, La Esperanza, Justicia, Salto del Burro, La Mesa, Mesa del Castaño, Santa María, Ferminera, El Calvo, La Dehesa y del Cerro de la Orden. Si, en definitiva, en sólo una parte de ellas podemos certificar que fueron beneficiadas durante el periodo republicano,

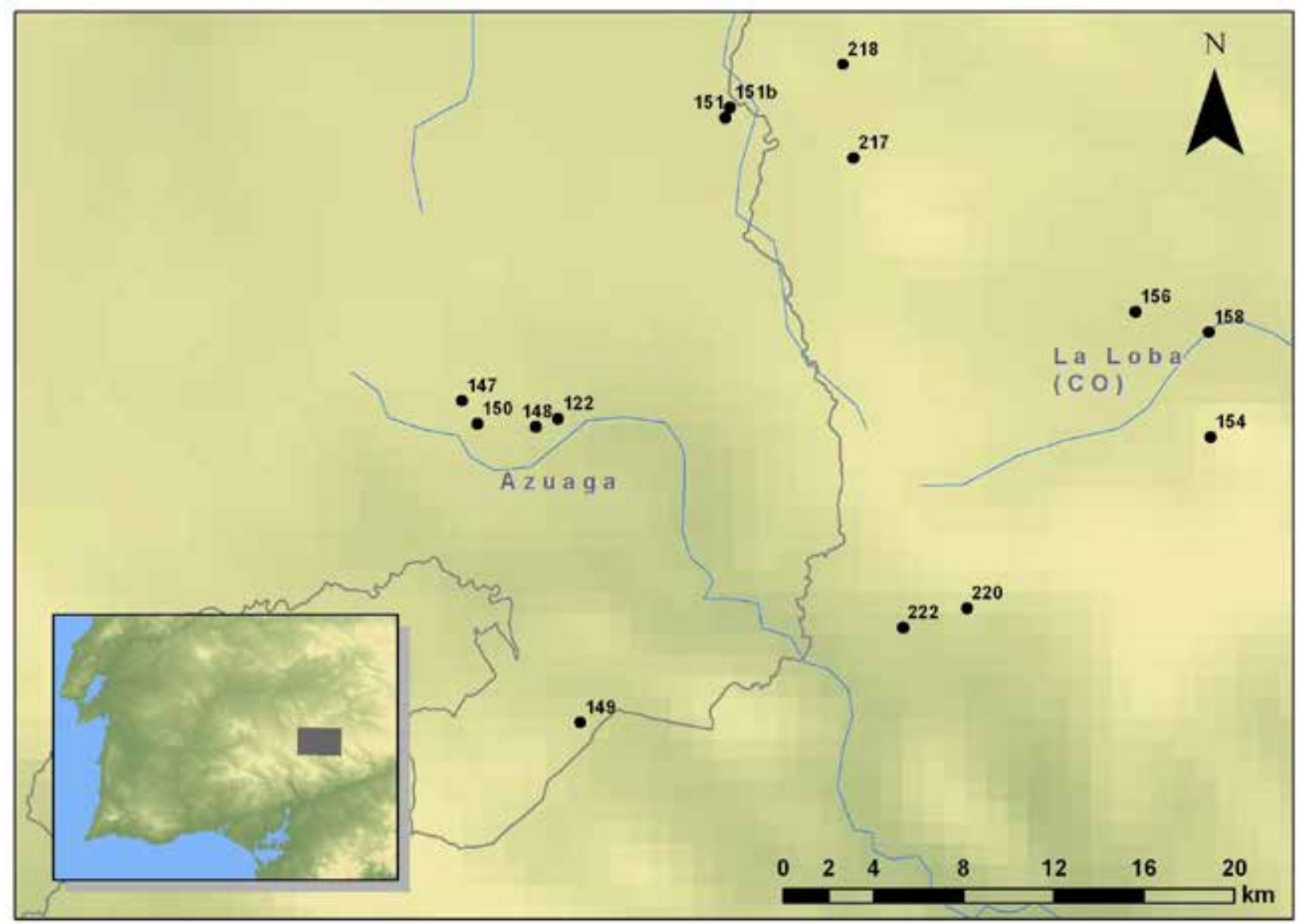

Figura 5. Mapa de situación de los indicios mineros de época romana de la comarca de Azuaga, al SE de la provincia de Badajoz: nº 122 Cero del Castillo (Azuaga, BA), nº 147 El Triunfo (Azuaga, BA), nº 148 Las Musas (Azuaga, BA), $\mathrm{n}^{\circ} 149$ Pilares de Téllez (Azuaga, BA), nº 150 El Carneril o Arroyo Jituero (Azuaga, BA), n 151, El Revuelo (Fuente Obejuna, CO), n⿳0 154 Ermita de San Bartolomé (Fuente Obejuna, CO), nº 156 La Loba (Fuente Obejuna, CO), nº 158 Masatrigo (Fuente Obejuna, CO), no 217 (Navalespino), nº 218 Santa Bárbara (Fuente Obejuna, CO), n 220 Piconcillo (Fuente Obejuna, CO), $n^{\circ} 222$ Lagunilla (Fuente Obejuna, CO). 
en conjunto ponen de manifiesto esa intensidad en la explotación de los recursos, fundamentalmente el plomo argentífero durante época romana, sobre todo en momentos tempranos.

Algo más alejado del núcleo principal de las minas de Azuaga, encontramos el interesante caso de El Revuelo, junto a la orilla del río Zújar, que sirve de límite natural de las provincias de Córdoba y Badajoz. Reconocemos la existencia de al menos dos núcleos distintos, aunque próximos entre sí. En uno de ellos se han identificado fragmentos de vajilla de barniz negro y de ánforas itálicas, además de una notable presencia de escorias de fundición. El otro punto obedece nuevamente a una plataforma enmarcada en un espigón fluvial, donde las escorias logran colorear de negro la superficie del terreno; también aquí se encuentran presentes las ánforas del tipo Dr. 1 y otras cerámicas de ascendencia romana, además de un bloque de mineral de plomo.

A muy pocos kilómetros al otro lado del río, ya en la provincia de Córdoba, las minas y fundiciones de Navalespino y de Santa Bárbara parecen definir una nueva concentración, equidistante de las actuales localidades de Azuaga y de Fuente Obejuna, en cuyo término encaja el importante centro minero republicano de La Loba. Desde el punto de vista geológico e incluso arqueológico, ambos espacios son el uno proyección natural del otro. Las mineralizaciones en el ámbito cordobés -como las de Azuaga, en Badajoz- son del tipo BPGC (blenda, pirita, galena y calcopirita), la mayoría galenas -plata y plomo-, como La Loba -en el centro de otras menores-, San Bartolomé, Santa Bárbara, Navalespino, La Lagunilla y Piconcillo. En todas estas minas, reabiertas también durante la industrialización contemporánea, es posible probar su arranque como explotaciones mineras ya en época republicana (Domergue, 1987, 132, fig. 42-E; Vaquerizo et alii, 1994, 197, nota 4; Arévalo, 1996, 63; García Romero, 2002, 165-166).

Particularmente interesante en todo este espacio es La Loba, tal vez el enclave minero mejor conocido desde el punto de vista urbanístico y material, gracias a la serie de trabajos de J. M. Blázquez y C. Domergue (Blázquez Martínez, 1981; 1982-83; 1988; Blázquez et alii, 2002). En él se han definido calles y patios que organizan el espacio interior, estancias que se relacionan con usos metalúrgicos y unos conjuntos cerámicos y metálicos que permiten una interesante propuesta cronológica. De todo esto, por el momento nos interesa el ajustado intervalo

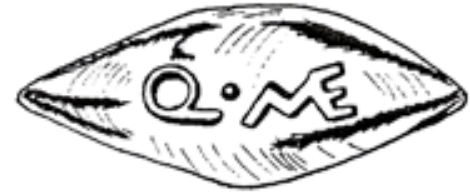

Figura 6. Dibujo de uno de los proyectiles de honda hallados en el Cerro del Castillo de Miramontes, Azuaga (Badajoz); según C. Domergue (1970, fig. 3).

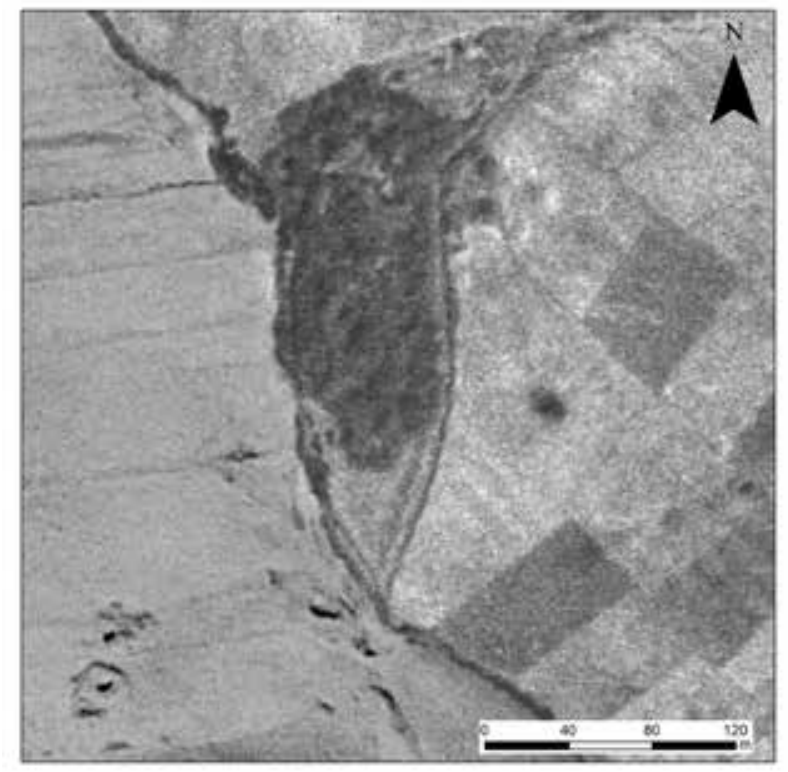

Figura 7. Fotografía aérea -“vuelo americano” de 1956 (fuente: IDEEX-Junta de Extremadura)- del sitio arqueológico de El Carenil o Arroyo Jituero (Azuaga, $\mathrm{BA}$ ) donde se aprecia un surco que define la planta de un recinto en forma de "quilla" de barco.

de fechas, entre el 120 y el 90 a.n.e. (Blázquez Martínez, 1982-83, 38-39; 1988, 118; Blázquez et alii, 2002, 400), refrendado desde los estudios cerámicos y numismáticos (Passelac, 2002; Otero, 1993, 52-53; Chaves y Otero, 2002, 210; Chaves et alii, 2005, 487-488).

\section{MinAS, MONEDAS Y EJÉRCITO}

Ya he apuntado dataciones, como la de La Loba, apoyadas en los valores numismáticos, que marcan un intervalo quizás asumible por los demás índices y sitios. El caso extremeño de Hornachuelos, a partir del estudio del conjunto monetario -quizás menos concluyente que el anterior-, no se mostraría tan distinto. Después de obviar aquellas acuñaciones más antiguas -moneda de plata romana y bronces 


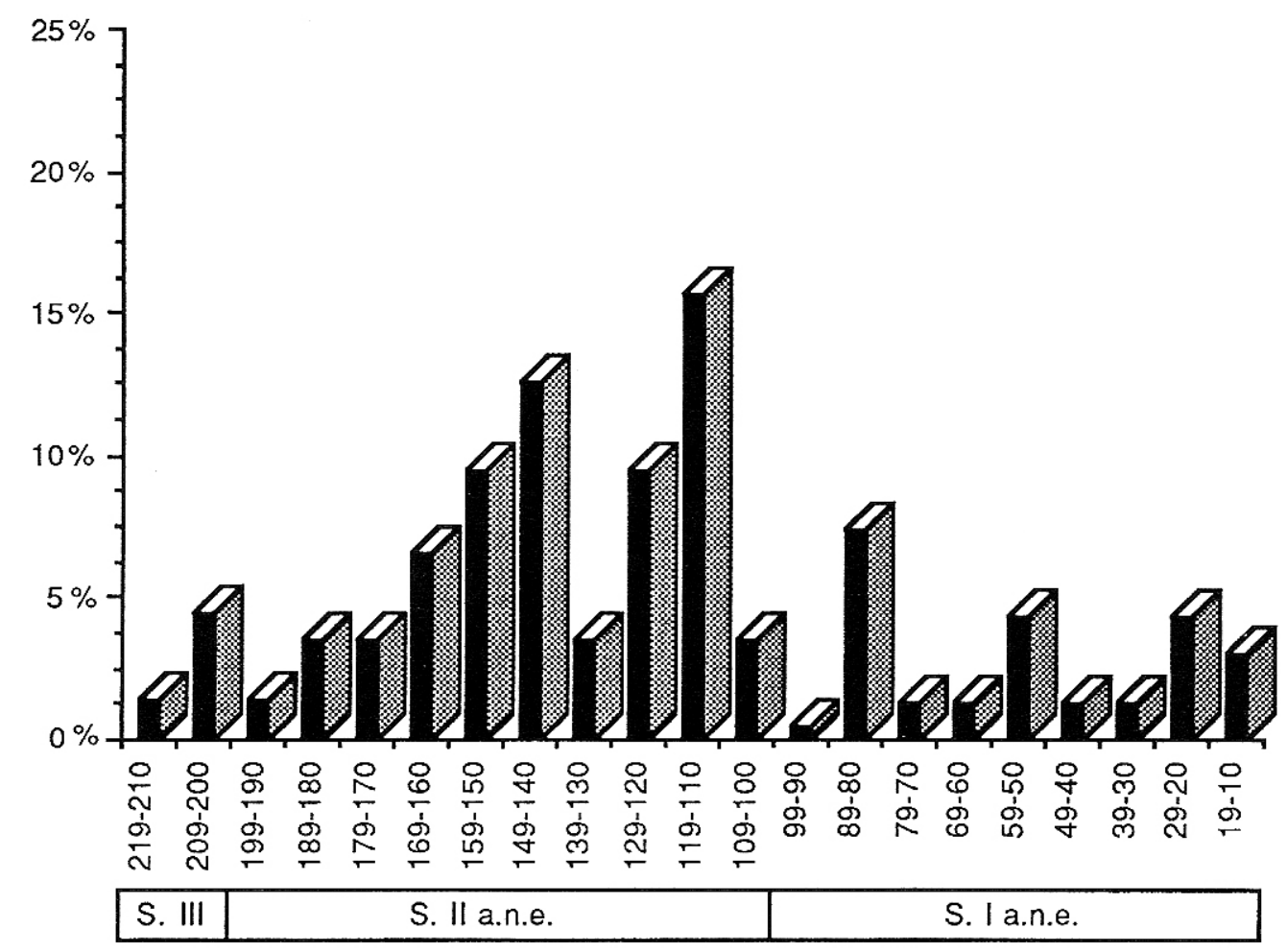

Figura 8. Gráfico estadístico que representa los intervalos cronológicos de las monedas del enclave de Hornachuelos; según Jiménez (1990b, gráf. 1).

hispano-púnicos de Carthago Nova y Gades, de finales del siglo III e inicios del II a.n.e. (Jiménez, 1990b, 27, 29, 35, 65)- y tal vez residuales, debemos contemplar dos momentos especialmente significativos en la provisión de este enclave minero (fig. 8). Más de la mitad del numerario itálico corresponde a emisiones del siglo II a.n.e. -el 67\%- y sobre todo a partir del ca. 150 a.n.e. -el 41,23\% de toda la moneda romana- (Jiménez, 1990b, 65). Por otro lado, en términos absolutos, el intervalo comprendido entre el último tercio del siglo y hasta el final de las Guerras Sertorianas resulta claramente mayoritario -el 46,15\%- (Jiménez, 1990b, 86, 99; García-Bellido, 1995, 283; Blázquez Cerrato, 1995, 244-245, 253; 2002, 192-193). Estas son las fechas en las que se vienen encuadrando las emisiones del área nororiental, entre las que destaca absolutamente el numerario de Sekaisa, con un 64\% del total de la moneda celtibérica (Jiménez, 1990b, 74, 84), en concreto la serie más tardía -del "grupo de los dos delfines” (V 65, 6-7, 11 y 13)-, cuya cronología pudiera situarse en las décadas en torno al cambio de siglo -II y I a.n.e.- (Villaronga, 1979, 194-195; Jiménez, 1990b, 74-75).
En relación a las cecas meridionales, destacan de forma significativa las de Castulo y Obulco, ciudades ambas cuya vinculación a la minería de Sierra Morena es clara -particularmente la primera(García-Bellido, 1982). En este sentido, el comportamiento numismático de Hornachuelos parece seguir el patrón común a los demás establecimientos mineros del mediodía peninsular (García-Bellido, 1995, 276; Chaves, 1987-88, 631, 633; Blázquez Cerrato, 2002, 194).

En estos mismos términos, podrían establecerse ciertos paralelismos con otro de los núcleos mineros argentíferos de la región. En el entorno del enclave cacereño de Villasviejas del Tamuja, rodeado de filones argentíferos explotados durante época romana y enormes escoriales que denuncian su beneficio (González y Heras, 2010, 884, fig. 9) se ha acumulado hasta hoy un número muy significativo de monedas de cronología republicana (García, 1989; Sánchez y García, 1989; Hernández et alii, 1989, 132; Hernández y Galán, 1996, 73, 126-128; Blázquez Cerrato, 1995; 2002; 2010; Chaves, 2006). En más de una ocasión se ha puesto de manifiesto la interesante representación de piezas de aquella ceca noro- 
riental de Sekaisa y, nuevamente, los hegemónicos porcentajes de su serie avanzada, que se interpretan en relación con un "contacto íntimo entre Celtiberia y la región extremeña” (Blázquez Cerrato, 1995, 253). Sin embargo, hemos de considerar con atención la revisión que, de una forma u otra, se hace de este numerario -en sintonía con otras cecas del NE- y que permite en cambio plantear su relación con los auxiliares hispanos en el ejército de Roma (López, 2014, 403-406, 411).

También aquí se repite esa primacía de los ases castulonenses entre el numerario hispano-meridional. La mayoría corresponden a la serie más reciente $-\mathrm{VI}^{\mathrm{a}}$-, cuyas fechas avanzan hacia el cambio de siglo -II al I a.n.e.- (Blázquez Cerrato, 1995, 251, fig. 4; Chaves y Otero, 2002, 203). De nuevo, junto a éstas, aparecen las de Obulco y, en este sentido, deseo resaltar -a propósito de los semises de estas cecas representados en el conjunto de Villasviejasla apreciación que ya hiciera C. Blázquez sobre su posible carácter de imitación y que pone en relación con un contexto presumiblemente militar de Riotinto (Chaves, 1987-88, 632, 635; Pérez y Delgado, 2007a, 94, 97, 101) y con otras piezas de Hornachuelos (Blázquez Cerrato, 1995, 251, nota 37).

De hecho -entroncando con esta última idea- es esa curiosa afınidad o proximidad con lo militar lo que pudiera explicar incluso esa extraña semejanza entre el comportamiento monetario apreciado en Villasviejas y la provisión observada en el campamento de Cáceres el Viejo. En este punto creo interesante recoger una breve reflexión del profesor Villaronga a propósito del análisis del conjunto de este cuartel militar cacereño. Decía que pareciera "la bolsa de un soldado que procedente de Cataluña las ha ido a perder a tierras extremeñas" (Villaronga, 1977, 38). Y es que podemos llegar a deducir un modo de aprovisionamiento común, acaso muy parecido, entre las supuestas comunidades mineras del Tamuja y el campamento, cercanos en todo caso, apenas $30 \mathrm{~km}$. Sin embargo, Hornachuelos -como adelantaba- se comporta de forma muy parecida, a pesar de que la distancia llegue a casi una centena de kilómetros.

La argumentación que nos pide este aspecto quizás resulte demasiado extensa para resumirla en estas líneas, aunque sí creo posible aportar algunos detalles del registro material que ilustre la idea que pretendo traer. Baste por el momento tener en cuenta que en todos los casos -más evidente en los mejor conocidos- se pueden apreciar signos mate- riales de la presencia militar. Tomemos en consideración, por ejemplo, esa vajilla metálica originaria de la Península Itálica, como los jarros "tipo Piatra Neamt", los cazos -aquellos simpula de origen romano-, o los coladores de bronce habituales en los ambientes castrenses, como Cáceres el Viejo, la auténtica referencia de la zona en este sentido. Las fíbulas, en particular aquellas "tipo Nauheim”, pero quizás también las "trasmontanas" -la Schüle 4h-, las "filiformes" o las "de "omega", aparecen tanto en los ambientes militares propiamente dichos como en los niveles de destrucción de algunos hábitats en que, de una forma u otra, puede detectarse esa misma impronta militar.

En otro momento tuve la ocasión de valorar todos estos criterios materiales en su conjunto y en contexto, estableciendo una pauta en la integración del registro arqueológico (Heras, 2015). Como parte del resultado, se obtuvo que el patrón material detectado en otros enclaves del SO peninsular, como Lomba do Canho, Monte do Castelinho, el Alto dos Cacos, Mesas do Castelinho, Cabeça de Vaiamonte o el Castrejón de Capote, parecía reproducirse en Villasviejas del Tamuja y en Hornachuelos, pero también en La Loba, el "centro" de la minería del NO cordobés. A través del patrón monetario (López, 2007; 2010; 2014) y del balance conjunto de los hábitos alimenticios, del vestido o la panoplia militar es posible detectar esa misma impronta -a veces sutil- de los ejércitos, apostados en determinados lugares por cuestiones logísticas y estratégicas (Ñaco, 2001; 2003,198-199; 2010a; 2010b; 2012; Ñaco y Principal, 2012; Fabião, 2007, 128-130; Cadiou, 2008, 327-353, 356; Heras, 2015, 614-662).

No debe extrañarnos la habitual presencia de militares en ambientes mineros. Riotinto es tal vez el gran centro de la minería republicana y altoimperial del SO peninsular, con una interesante estratigrafía vertical y horizontal que demuestra el interés de Roma por los recursos metálicos que contenían las masas polimetálicas de su subsuelo. Era también el gran receptor del plomo hispano, necesario -como se ha dicho- para la síntesis de la plata a partir de los compuestos argentíferos (como la argento-jarosita) y por tanto dependiente de los circuitos de este metal (Domergue, 1990, 5658; Domergue y Rico, 2014, 155). En este enorme complejo minero, por ejemplo, se logra la constatación arqueológica de la actividad del ejército; en particular, hemos de observar determinados objetos aparecidos en el Cerro del Moro, relacionados con 
un supuesto control -quizás estable- de las explotaciones inmediatas (Pérez y Delgado 2007a, 110-112, 122). Los argumentos materiales en este espacio corresponden, no obstante, ya a un tiempo algo más avanzado (Pérez y Delgado, 2007a, 125), aunque tal vez tampoco falten las evidencias arquitectónicas, estables y tempranas, como la construcción del Castillejo de El Campillo (Pérez y Delgado, 2009, 52, 56).

Ejemplos de control militar, como los diseños para la defensa observados en otros puntos del mediodía peninsular (p. ej.: Maia, 1986; Maia y Maia, 1996; Brotons y Murcia, 2006; López-Mondéjar, 2009; Murcia et alii, 2008; Adroher et alii, 2006; Torres y Gutiérrez, 2004; Fernández y Zarzalejos, 2003; Chapa et alii, 2004) garantizarían esa seguridad necesaria para la rentabilidad de las explotaciones. Cuestión bien distinta es -desde mi punto de vista al menos- la posibilidad de un apoyo extra a ese control, un esfuerzo o refuerzo estratégico, materializado en una estancia transitoria de efectivos militares durante momentos de estrés bélico. La documentación de proyectiles de honda en ciertos enclaves, significativos en relación con el dominio de rutas de acceso a los espacios mineros fundamentales, puede ser entendida efectivamente como síntoma de esa presencia. Particularmente interesante es el caso de las balas de plomo epigráficas de San Sixto (Encinasola, Huelva), con la cartela relativa a Sertorio (Chic, 1986; Pérez, 1987, 34-36; Pérez y Delgado, 2007a, 108-110), o las halladas en Azuaga, en referencia a Metelo-Q[uintus] (Caecilius) MET[ellus]-(Domergue, 1970, 610), oponente directo del anterior durante las Guerras Civiles de la tercera década del siglo I a.n.e. Este último caso viene a reforzar el temprano interés de Roma por la explotación de las galenas argentíferas -ricas en plomo- de este sector de la vertiente septentrional de Sierra Morena, en cuyos filones ya habíamos destacado la presencia de ánforas republicanas, y del que forman parte igualmente aquellas minas del ámbito cordobés de La Loba -que también denota en su registro esa incidencia de lo militar (Domergue, 2002, 337)-, de Piconcillo, de NavalespinoSanta Bárbara-Revuelo, de Lagunilla, etc.

La preocupación por el control de las explotaciones pudiera estar detrás -como vengo sosteniendode esa ocupación militar del "castro" prerromano de Villasviejas del Tamuja y la extraña abundancia de armas en su necrópolis más tardía, El Romazal I, (Hernández, 1993; 2008; Hernández y Galán,
1996), de su comportamiento numismático, quizás también de la ceca monetaria "local" -Tamusia(Sánchez y García, 1988; Blázquez Cerrato, 1995; Burillo, 1998, 310; en contra Villaronga, 1990) o del conjunto de monedas cordobesas -emisión militar "de necesidad"-(Chaves, 2006, 390). En el valle del Guadiana, Hornachuelos mostraba un patrón monetario semejante, pero también una significativa cantidad de glandes de plomo; o también La Minilla de Garlitos, con balas de honda y numerario de los mismos talleres nororientales (Tejada, 1997, 49-50).

\section{El PLOMO, LA PLATA Y SU CONTEXTO HISTÓRICO}

Parece claro, a estas alturas, que la minería romana durante el periodo republicano en la cuenca media del Guadiana -en el contexto de la fachada norte de Sierra Morena- no debió ser en modo alguno testimonial ni un aspecto trivial en la política expansionista seguida por el Estado. El testimonio aportado por los autores romanos suponía ya una clamorosa advertencia acerca de la riqueza metalífera de estas tierras; sin embargo muy poco conocíamos -y en buena medida seguimos sin conocer- su auténtica dimensión arqueológica. Baste valorar la presencia de determinados indicios materiales -cerámicos, metálicos, epigráficos e incluso numismáticos- para comprobar la densidad de este mapa de puntos en que se convierte nuestra cartografía de la minería argentaria republicana. Tal vez quepa, incluso, añadir a ésta al menos una parte de la infinidad de filones explotados durante el periodo romano, no sólo para hacernos idea de la verdadera entidad que adquirió esta actividad, sino lo que en realidad supuso para Roma en aquellos primeros tiempos.

Pero, ¿acaso estamos seguros de cuáles fueron esos "primeros tiempos" de la minería en esta parte de la Península Ibérica? Podemos convenir que Roma asume la explotación de las minas de Carthago Nova tras derrotar a los cartagineses y arrebatarles esta importante fuente de poder. Cuestión bien distinta es atisbar, desde el dato literario y arqueológico, el modo de acometer tal actividad, si directamente por parte de los gobernadores provinciales o si a través de un régimen de arrendamiento y, por tanto, indirecto. Por el pasaje de Livio (34, 21) sabemos que, a comienzos del siglo II a.n.e., Catón graba al hierro y a la plata. A partir de ello, muchos investigadores han planteado la existencia de esta segunda modalidad para la gestión de las 
explotaciones, confiándolas a particulares -publicani- o a agrupaciones de ellos, aquellas societates publicanorum (Nicolet, 1979; Blázquez Martínez, 1989, 120; Mangas y Orejas, 1999, 217). Sin embargo, no podemos estar seguros de ello sólo con este dato; más al contrario, no son pocas las críticas que han suscitado estas fechas tan tempranas (Richardson, 1976, 140-144, 146; Blázquez Martínez, 1996, 180-181; Naco, 2003, 119-120). Es posible que hasta bastante tiempo después no se produjera el cambio en el modelo económico que posibilitase que las minas recayeran en efecto en manos de arrendadores particulares. Al menos Polibio (Estr., 3, 2, 10) -que estuvo en Hispania durante las Guerras Celtibéricas-, parece ponerlo de manifiesto al hablar de las minas de plata cartaginesas; hasta entonces, la responsabilidad debió ser directamente la de los gobernadores provinciales (Frank, 1933a, 138, 154, 157, 257; 1933b, 7; Badian, 1972, 32; Gabba, 1954, 297; 1973, 290; Blázquez Martínez, 1970, 131; 1978, 37; 1989, 119; Broughton, 1974, 12; Mangas y Orejas, 1999, 210).

No faltan tampoco propuestas que tratan de profundizar aún más en unos cambios de amplio calado en el sistema económico, que alcanzan a distintos aspectos de la administración de las provincias -en principio Asia, pero extensible a África, Sicilia e Hispania- y que, tal vez, cobran sentido en relación con las reformas graquianas (Erdkamp, 1998, 111; Ñaco, 2003, 115-116, 119-121; 2007, 223; 2010a, 174; 2010-11, 304). Estas mutaciones en la política económica pudieron afectar de lleno a la gestión de los recursos metalíferos, particularmente interesantes -por su dimensión- para las arcas de la República. Esta idea podría quedar en cierta medida reforzada por la datación que aporta el dato numismático -según hemos visto en el capítulo anterior-, donde la más rotunda incidencia de la moneda en los ambientes mineros recae en fechas del último tercio del siglo II a.n.e., una vez finalizadas las Guerras Lusitanas y lograda la supuesta pacificación de estas tierras (Chaves, 1994, 115). Éste debió ser un momento muy favorable para la labor de esas compañías en la Península, e incluso más el último cuarto de ese mismo siglo, si tenemos en cuenta la iniciativa legal que significó, en el ámbito de la contratación y explotación de servicios públicos, la Lex Sempronia de provincia Asiae del año 123 a.n.e. (Erdkamp, 1998, 114-116; 2010, 135-143; Ñaco, 2010a, 174; 2010-11, 304; Morillo y Salido, 2010, 135-164; Kay, 2014, 59-61, 83).
Sea como fuere, el tiempo en que coinciden los más sintomáticos aportes monetarios en los conjuntos de las minas republicanas de la región es -insistentemente- el de las dos o tres últimas décadas del siglo II a.n.e. y las primeras del siguiente. Éste parece al menos el caso de Hornachuelos o Villasviejas del Tamuja, acorde con lo observado en la Loba (Chaves y Otero, 2002, 210; Chaves et alii, 2005, 487-488), quizás también Valderrepisa (Fernández y García, 1993, 30-38; Marcos, 1993, 49) o las fases republicanas de Riotinto (Chaves, 1986; Pérez y Delgado, 2007a, 94, 96-97, 101).

Incorporando otros argumentos, este periodo de finales del siglo II a.n.e. es también el del desembarco masivo de las ánforas vinarias Dr. 1, que "inundarán” las minas hispanas (Domergue, 1990, 356). La actividad de los negotiatores, muchos de ellos venidos del ámbito campano (Beltrán, 1947, 202-208; Domergue, 1965; 1966; 1990, 327), pudo acarrear este efecto colateral, pues el establecimiento de las nuevas redes mercantiles entre el $\mathrm{S}$ de la Península Itálica e Hispania debió favorecer esa transacción: el transporte de vino en estas pesadas ánforas hasta los puertos y minas de la Ulterior para devolver los barcos cargados de los metales hispanos.

Abundar en esta posibilidad permite, no obstante, alguna consideración más, aún con interesantes derivadas económicas. Cabe imaginarse una triple utilidad en este tipo de canje. Esto es, reportar este preciado vino al consumo interno de la mina, satisfaciendo parte de las necesidades logísticas de estos complejos, colocar el excedente productivo itálico $\mathrm{y}$, desde el punto de vista técnico, aprovechar el elevado peso del recipiente cerámico -más su contenido- como "carga de lastre" en los barcos que se dirigen a Hispania a buscar el preciado metal, mayoritariamente plata y plomo.

$\mathrm{Y}$ es que -no debemos olvidarlo- el destino de la producción, en general, es Roma y sus ciudades $\mathrm{y}$, en último término, la rentabilidad económica de los inversores que, al final de la cadena, habrá de revertir en el erario de la Res Publica. Los metales cumplirán tareas diversas una vez extraídos de la fundición. Así la plata irá dirigida en buena medida a satisfacer las necesidades monetarias de un Estado Romano en expansión. Por su parte, el plomo se emplea como material de construcción, en las conducciones hidráulicas y como aporte interesante en las aleaciones, como la que da lugar al aes campano a que me refería al comienzo del trabajo. Sin embar- 


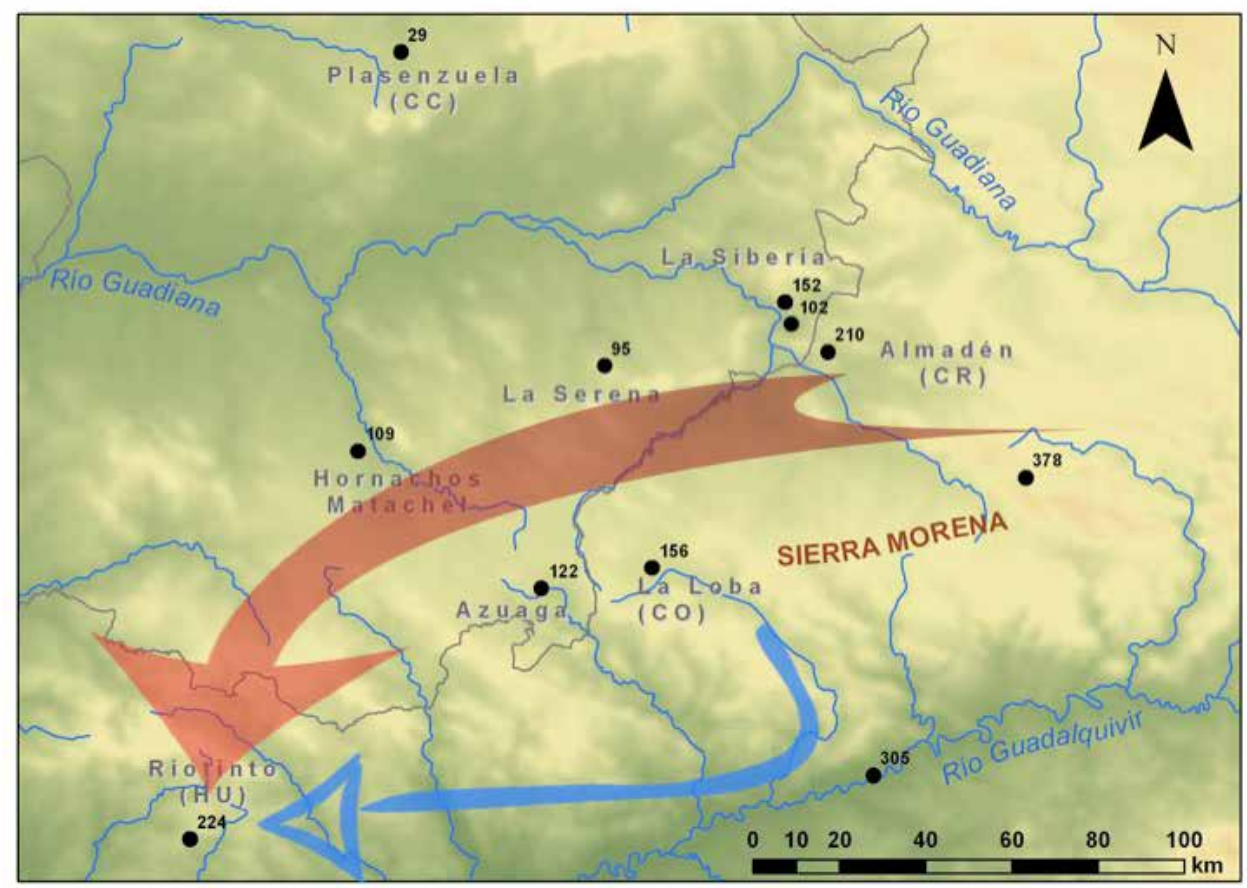

Figura 9. Propuesta de rutas generales de provisión de plomo procedente de la minas de Sierra Morena occidental. Se sitúan aquellos sitios relacionados con la minería republicana consignados en el texto: $\mathrm{n}^{\circ} 29$ Villasviejas del Tamuja (Botija, Cáceres), n ${ }^{\circ} 95$ Mina Gamonita (Castuera), n 102 Cerro del Cabezo (Capilla, BA), ${ }^{\circ} 109$ Hornachuelos (Ribera del Fresno, BA), $\mathrm{n}^{0} 122$ Cerro del Castillo (Azuaga, BA), n 152 La Minilla (Garlitos, BA), n 156 La Loba (Fuente Obejuna, CO), $\mathrm{n}^{\circ} 210$ Fundición San Pablo (Chillón, CR), $\mathrm{n}^{\circ} 224$ Cortalago (Riotinto), $\mathrm{n}^{\circ} 305$ Córdoba; $\mathrm{n}^{\circ}$

go, he hecho alusión también a uno de los procesos físicos más importantes que tienen que ver con la producción de la plata y que requiere el concurso del plomo. La plata contenida en aquellas masas argentíferas de Riotinto debe ser liberada añadiendo este otro metal, del que resulta deficitario esta cuenca minera, en el transcurso de la reducción del mineral.

Seguramente el plomo se importó de forma masiva para cubrir ese déficit y los lingotes del área cartaginesa -resultantes del tratamiento del mineral argentífero- constituyeron el grueso del suministro. Ahora bien, no podemos estar seguros que todo el plomo importado proceda de este centro productivo del SE, más aún cuando no tan lejos de la cuenca minera de Riotinto se localizan todas esas fundiciones que se extienden a lo largo de la fachada norte de Sierra Morena y que hemos repasado líneas atrás. El metal procedente de las fundiciones de Carthago Nova -y su entorno inmediato- se habría embarcado y seguido prácticamente toda la costa meridional hispana hasta los puertos de Huelva o Sevilla y, de ahí, transportados hacia el interior onubense, donde se encuentran estas minas. La alternativa que planteo bebe en parte de la vecindad de los filones de Badajoz (Azuaga, Hornachuelos, La Serena o La Siberia), de la provincia de Córdoba (La Loba, Piconcillo, Lagunilla, Navalespino, Santa Bárbara, etc.) o de Ciudad Real (la comarca de Almadén: San Pablo, Quinto del Hierro, Mina Diógenes, Valderrepisa, entre otras), estrechamente interrelacionados desde el punto de vista geológico.

Debemos considerar, por otro lado, la interpretación de un lingote del Museo de Huelva, aparecido en la zona de stock de gossan, próximo al sitio de Cortalago, clave para entender la estratigrafía de la minería romana de Riotinto. Se trata de una pieza anepígrafa, con sello en forma de estrella de cinco puntas, identificada con la iconografía de Tanit $\mathrm{y}$-con tal razonamiento- puesta en relación con los plomos monetiformes de las sociedades de publicanos de Sierra Morena (Pérez y Delgado, 2009, 72). De alguna forma, esta lectura avalaría acaso cierto suministro derivado de la producción de otras zonas limítrofes de la Ulterior, en que se insertan todas estas explotaciones del SO peninsular. 
Si estas explotaciones -como hemos visto- llegaron a funcionar a la vez, las distancias que habrían de superarse entre cada uno de estos centros mineros y el de Riotinto, en términos absolutos, son mucho menores. Indudablemente, no podemos olvidar que estos otros desplazamientos deben hacerse por vía terrestre, pero también lo fue el remonte desde los puertos occidentales hacia las metalurgias del interior onubense. Tampoco debemos dejar de tener en cuenta ciertos aspectos reseñados a propósito del estudio numismático, como la reflexión que sugiriera la profesora F. Chaves -seguida por otrosa propósito de un eventual "arco de comunicación" entre las áreas de Ciudad Real-Córdoba y el norte de Huelva a través del sur de Extremadura (Chaves, 1987-88, 633, nota 40; Fernández y García, 1993, 35). (fig. 9)

Volviendo al argumento monetario, hemos de considerar la presencia misma de monedas de determinadas cecas portuarias meridionales en los conjuntos de las minas (Chaves y García, 1994, 384387; García et alii, 2008, 255-256). Las de Ilipa, por ejemplo, están presentes en Riotinto (Arévalo, 1994, 39-48; 2000, 49-51; Pérez y Delgado, 2007a, 102) y su identificación en sitios como Capote o la Sierra de la Martela (Berrocal y Canto, 1990, 74; García-Bellido, 1995, 280, 285; Enríquez y Rodríguez 1988, 121), ambos en el paso más directo entre esta área onubense y Extremadura, podrían estar denunciando tal vez el modo de salida de su producción (Domergue, 1990, 164; García-Bellido, 1995, 280; Chic, 2007, 152).

\section{A MODO DE SÍNTESIS: EL PLOMO COMO RECURSO ES-} TRATÉGICO

Llegado el punto de sintetizar algunas de las cuestiones vertidas hasta ahora a propósito de nuestro ámbito particular de estudio, considero interesante rescatar aquellas ideas que pudieran resultar más definitorias de esta minería del plomo del SO, en términos más generales e históricos. Quizás la primera de ellas sea la necesidad de considerar la relevancia de este sector económico -el de la minería argentífera- como motor esencial en la progresión de la conquista romana de estos territorios. La cantidad y significación de las explotaciones de galenas con indicios de labor durante el periodo romanorrepublicano debe ser un síntoma decisivo en este sentido y no solamente el índice de transformación del medio, en buena medida condicionado por la geología o el tipo de mineralización beneficiada.
No debe extrañarnos tampoco que, si bien el objetivo esencial de la industria minera republicana en Hispania pudo haber sido la plata, el plomo fuera algo más que un producto secundario en los procesos de transformación de ésta. Cuanto menos, su lugar -en orden de importancia- no debió quedar demasiado lejos. La geología, la física y la química de la plata están íntimamente ligadas a la del plomo, en la Naturaleza y en esos procesos. El mineral de la galena argentífera contiene ambos elementos $\mathrm{y}$ éstos pueden individualizarse -el uno respecto del otro- mediante técnicas conocidas desde hacía siglos, como la copelación. Sin embargo, la primera necesita del segundo en otro tipo de mineralizaciones, muy importantes en grandes regiones mineras como la de Riotinto, deficitaria en plomo, que es necesario importar. Hay que tener en cuenta, por otro lado, que este metal constituye un elemento clave para otros usos, como la edificación o las conducciones hidráulicas, pero también en aleaciones tan interesantes como el aes o "cobre campano" del que hablaba Plinio, apreciado por su versatilidad.

De estas últimas líneas se deduce, en efecto, un peso cualitativo per se de la industria del plomo, pero también de su papel en el rentable negocio de la plata, patrón metálico en que se basa -al fin y al cabo- la economía monetaria de la República romana. La imposibilidad de disociar el negocio de ambos metales hace necesaria absolutamente -al menos desde mi punto de vista- la interconexión de los distritos mineros, dependientes los unos de los otros. En esta interdependencia resulta obligado arbitrar políticas empresariales coordinadas, emanadas probablemente desde los grandes capitales itálicos que ven en las agrestes montañas de la Ulterior una tierra de oportunidades económicas. De un lado, las minas de plata de Sierra Morena, con su remanente de plomo satisfacen las necesidades de las ciudades y -tan sólo en parte- a las industrias argentíferas de la Faja Pirítica Ibérica, como Riotinto. Uno y otro metal colmarán buena parte de las ansias de riqueza de los inversores romanos, muchos de ellos suritálicos, según se deduce de la antroponimia reflejada en las cartelas de los lingotes. De otro lado, otros empresarios campanos -tal vez los mismoslogran colocar en las jóvenes explotaciones mineras su excedente de producción, ese vino contenido en aquellas ánforas Dr. 1A, que atestan las minas republicanas hispanas.

Estas ánforas son también un fósil-guía de un tiempo determinado. Su llegada masiva a Hispania 
debió producirse durante el último tercio del siglo II e inicios del I a.n.e., coincidiendo con el momento de actividad de las minas, si consideramos las deducciones hechas a propósito del análisis numismático. Las explotaciones argentíferas extremeñas, las cordobesas -con referentes tan señalados como La Loba- o las del área almadenense -oeste de la provincia de Ciudad Real-, y en sintonía con una parte significativa de la secuencia estratigráfica de Riotinto, convivieron y quizás colaboraron estrechamente entre sí. Este momento reflejado en los índices cronológicos de las minas -monedas, ánforas, etc.- tal vez no sea casual. El supuesto fin de las grandes guerras de la segunda mitad del siglo II a.n.e., como las Celtibéricas o las Lusitanas, pudo hacer atractivo -ahora sí- el negocio de la plata en las regiones interiores de la Península Ibérica que conocía Roma. En un clima de mayor estabilidad -al menos transitoria- cabía arbitrar medidas económicas importantes por parte de la República, como las reformas que propiciaron el arraigo del sistema de arrendamientos de servicios públicos, gracias a leyes como la Lex Sempronia de provincia Asiae. El abastecimiento militar fue uno de ellos, pero -sirva como hipótesis- también la explotación de los recursos mineros, controlados hasta entonces por los responsables provinciales, y que pudieron pasar a manos de empresarios, esos publicani o societates publicanorum cuyos nombres aparecen impresos en sellos y lingotes.

Esto -como digo- podía ser gracias a la garantía de seguridad que le ofrecía el propio ejército, cuya presencia está plenamente reflejada en el registro material de los enclaves mineros, donde fue determinante en instantes muy concretos durante la convulsa política interna de la Roma republicana. La particular incidencia de la moneda "celtibérica", aportada por los soldados en cada conjunto, la reiteración de otros síntomas materiales de la actividad de las tropas romanas -itálicos y auxiliares- o la masiva presencia de balas de honda en los centros mineros o sus vías de acceso, algunos con el nombre de los generales enfrentados, refuerzan esta idea de necesidad acuciante de control de estos recursos estratégicos.

\section{Agradecimientos}

No quisiera concluir esta reflexión sin antes reconocer la ayuda, los consejos y apoyo de algunas personas. A Juan Aurelio y Aquilino, a Jordi y a Toni, a E. Rebollada, a Chema, Martín, José
Miguel, Javier Jiménez, a Antonio González y a otros tantos amigos, con cuyo aliento y experiencia siempre he podido contar.

\section{Bibliografía}

Adroher Auroux, A. M., Caballero Cobos, A., Sánchez, A., Salvador, J. A. y Brao, F. J. (2006), "Estructuras defensivas tardorrepublicanas en el ámbito rural de la Bastetania”, Arqueología militar romana en Hispania. Producción y abastecimiento en el ámbito militar (Morillo, A., eds.), León, 625-638.

Alonso, J. (2005), Excavaciones en el Cerro del Castillo de Azuaga. Escuela-taller "Sinfonía del Agua", Memoria de trabajos inédita.

Alvarado Gonzalo, M. de (1994), Informe sobre la campaña de excavaciones efectuadas en el poblado de "Los Castillejos" (Área II). Diciembre de 1994, Memoria de los trabajos inédita.

Arévalo González, A. (1994), "La dispersión de las monedas de Ilipa Magna", Actas del IX Congreso Nacional de Numismática, Elche, 3948.

Arévalo González, A. (1996), "La circulación monetaria en las minas de Sierra Morena: El distrito de Córdoba", Homenaje a Mercedes Rueda Sabater y Juan Ignacio Sáenz Díez, vol. 1, Nvmisma, 237, año XLVI, Madrid, 51-82.

Arévalo González, A. (2000), "La moneda hispánica en relación con la explotación minera y agrícola”, Actas del IV Curs d'Historia Monetària d'Hispania, Moneda $i$ administració del territori, (Campo, M., ed.), Barcelona, 3756.

Badian, E. (1972), Publicans and Sinners, Oxford.

Blázquez Cerrato, C. (2002), Circulación monetaria en el área occidental de la Península Ibérica. La moneda en torno al Camino de la Plata, Archéologie et Histoire Romain 6, Montagnac.

Beltrán Martín, A. (1947), "Objetos romanos de plomo en el museo de Cartagena”, Memorias del Museo Arqueológico Provincial VIII, 202-209.

Berrocal Rangel, L. y Canto García, A. (1990), "Aproximación al estudio de la numismática prerromana del Suroeste peninsular: el ejemplo del Castro de Capote", Gaceta Numismática,

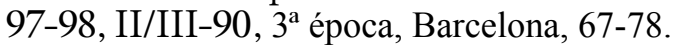


Berrocal Rangel, L. (1992), Los pueblos célticos del Suroeste de la Península Ibérica, Complutum extra, 2, Madrid.

Blanco Freijeiro, A. y Rothenberg, B. (1981), Exploración Arqueometalúrgica de Huelva, Ed. Labor, Barcelona.

Blanco Freijeiro, A., Luzón Nogué, J. M. y Ruiz Mata, D. (1970), Excavaciones arqueológicas en el Cerro Salomón (Riotinto, Huelva), Sevilla.

Blázquez Cerrato, C. (1995), "Sobre las cecas celtibéricas de Tamusia y Sekaisa y su relación con Extremadura", Archivo Español de Arqueología, 68, Madrid, 243-258.

Blázquez Cerrato, C. (2010), "El proceso de monetización de Lusitania desde el siglo I a. C. al siglo I d. C.", Actas de la VIIe Table Ronde internationale sur la Lusitanie romaine, Naissance de la Lusitanie romaine (Ier av. - Ier ap. J.C.), (Gorges, J. G. y Nogales Basarrate, T., eds.), Tolouse-Mérida, 405-435.

Blázquez Martínez, J. M. (1970), "Fuentes literarias griegas y romanas referentes a las explotaciones mineras de la Hispania romana", Actas del VI Congreso Internacional de Minería 'La Minería Hispana e Iberoamericana. Contribución a su investigación histórica, León, 117150.

Blazquez Martínez, J. M. (1978), Historia económica de la Hispania Romana, Madrid.

Blázquez Martínez, J. M. (1981), "Poblado de esclavos mineros en Fuenteobejuna”, Revista de Arqueología, 3 (marzo 1981), 7-12.

Blázquez Martínez, J. M. (1982-83), “Noticia sobre las excavaciones arqueológicas en la mina republicana de La Loba (Fuenteobejuna, Córdoba)”, Corduba Archaeologica 12, 29-39.

Blázquez Martínez, J. M. (1988), "La Loba. Mina y almacenes de finales de la República romana (120-80 a. C.) en Fuenteobejuna (Córdoba)", Historia 16, 146, Madrid, 118-128.

Blázquez Martínez, J. M. (1989), "Administración de las minas en época romana. Su evolución”, Minería y Metalugia en las antiguas civilizaciones mediterráneas europeas, Actas del Coloquio Internacional Asociado (Madrid, 1985), vol. II, (Domergue, C., coord.), Madrid, 119-131.

Blázquez Martínez, J. M. (1996), "Las explotaciones mineras y la romanización de Hispania", La romanización en Occidente (Blázquez, J.
M. y Alvar, J., eds.), Madrid, 179-200.

Blázquez Martínez, J. M., Domergue, C. y Sillières, P., dirs. (2002), La Loba (Fuenteobejuna, Cordoue, Espagne). La Mine et le village minier antiques, Ausonius Memories 7, Bordeaux.

Brotons Yagüe, F. y Murcia Muñoz, A. J. (2006), "El castellum tardorrepublicano del Cerro de las Fuentes de Archivel (Caravaca de la Cruz, Murcia). Estudio preliminar”, Arqueología militar romana en Hispania. Producción y abastecimiento en el ámbito militar, (Morillo, A., ed.), León, 639-653.

Broughton, T. R. S., (1974), "Some notes on Trade and Traders in Roman Spain", Polis and Imperium, Studies in Honour of E. T. Salomon (Evans, J. A. S., ed.), Toronto, 11-30.

Burillo Mozota, F. (1998), Los celtíberos. Etnias y Estados, Crítica, Barcelona.

Cadiou, F. (2008), Hibera in terra miles, Les armées romaines et la conquête de l'Hispanie sous la république (218-45 av. J.-C.), Casa de Velázquez, Madrid.

Casariego, A., Cores, G. y Pliego, F. (1987), Catálogo de plomos monetiformes de la Hispania Antigua, Madrid.

Chapa Brunet, T., Mayoral Herrera, V. y Uriarte González, A. (2004), "Recintos fortificados tardoibéricos en la región del Guadiana Menor. Propuestas de interpretación histórica y nuevos métodos de estudio", Torres, atalayas y casas fortificadas. Explotación y control del territorio en Hispania (S. III a. de C. - S. I de C.), (Moret, P. y Chapa, T., eds.), Jaén, 97-118.

Chaves Tristán, F. y Otero Morán, P. (2002), "Los hallazgos monetales”, La Loba (Fuenteobejuna, Cordoue, Espagne). La Mine et le village minier antiques, Ausonius Memories 7 (Blázquez Martínez, J. M., Domergue, C. y Sillières, P., dirs.), Bordeaux, 163-230.

Chaves Tristán, F. (1986), "Hallazgos de monedas en Riotinto (Huelva)", Estudios en homenaje al Dr. Antonio Beltrán Martínez, Zaragoza, 863-872.

Chaves Tristán, F. (1987-88), “Aspectos de la circulación monetaria de dos cuencas mineras andaluzas: Riotinto y Cástulo (Sierra Morena)”, Habis, 18-19, Sevilla, 613-637.

Chaves Tristán, F. (1994), "Indigenismo y romanización desde la óptica de las amonedaciones hispanas de la Ulterior", Habis, 25, Sevilla, 107120. 
Chaves Tristán, F. (2006), "Un hallazgo de monedas de Corduba en Extremadura”, Numisma, 250, enero-diciembre, año LVI, 363-392.

Chaves Tristán, F., García Vargas, E. (1994), “Gadir y el comercio atlántico a través de las cecas occidentales de la Ulterior”, Arqueología en el entorno del Bajo Guadadiana, Huelva, 375392.

Chaves Tristán, F., Otero Morán, P. y Gómez Tobío, B. (2005), "Los hallazgos monetales del poblado minero de La Loba (Fuenteobejuna, Córdoba). Análisis metalográficos”, Actas del XIII Congreso Internacional de Numismática (Madrid 2003), vol. I (Alfaro Asins, C, Marcos Alonso, C. y Otero Morán, P., coords.), Madrid, 487-496.

Chic García, G. (1986), “Q. Sertorius, procónsul”, en Actas de la reunión científica sobre "Epigrafía hispánica de época romano-republicana" (Zaragoza 1983), Zaragoza, 171-176.

Chic García, G. (2007), "Ilipa romana: entre el prestigio y el mercado", en Actas del I Congreso de Historia de Alcalá del Río "Ilipa Antiqva. De la Prehistoria a la época romana" (Ferrer Albelda, E., Fernández Flores, A., Escacena Carrasco, J. L. y Rodríguez Azogue, A., eds.), Sevilla, 149-170.

Chico, J. y Rubio, A. (1982), "Materiales mineros romanos del Museo Arqueológico Provincial de Badajoz”, Revista Museos, 2, 109-116.

Domergue, C. y Rico, C. (2014), "Les itinéraires du commerce du cuivre et du plomb hispaniques à l'époque romaine dans le monde méditerranéen", Actas du colloque de Bastia 'La corse et le monde méditerranéen des orígenes au moyen-âge: échanges et circuits commerciaux' (2013), 135-168.

Domergue, C. (1965), "Les Planii et leur activitée industrielle en Espagne sous la république", $\mathrm{Me}$ lélanges de la Casa de Velázquez, 1, 9-27.

Domergue, C. (1966), "Les lingots de plomb du Musée Archéologique de Carthagéne et du Musée Naval de Madrid", Archivo Español de Arqueología, 39, Madrid, 41-72.

Domergue, C. (1967), "La mine Antique de Diogenes (Province de Ciudad Real)", Mélanges de la Casa de Velázquez, 3, 29-91.

Domergue, C. (1971), "El Cerro del Plomo. Mina "El Centenillo" (Jaén)”, Noticiario Arqueológico Hispánico, 16, Madrid, 265-357.

Domergue, C. (1987), Catalogue des mines et des fonderies antiques de la Péninsule Ibérique, Publications de la Casa de Velázquez, Madrid.

Domergue, C. (1990), Les mines de la Péninsule Ibérique dans l'antiquité romaine, Roma.

Domínguez de la Concha, M. C. y García Blanco, J. (1992), "La tabla de las Cañas, (Capilla, Badajoz). Apuntes preliminares", Extremadura Arqueológica, II, Mérida-Cáceres, 235- 246.

Enríquez Navascués, J. J. y Rodríguez Díaz, A. (1988), "Campaña de urgencia en la Sierra de la Martela (Segura de León, Badajoz)", Extremadura Arqueológica, I, Salamanca, 113-128.

Erdkamp, P. (1998), Hunger and the sword. Warfare and food supply in Roman Republican Wars (264-30 B.C.), Amsterdam.

Erdkamp, P. (2010), "Supplying armies in the Iberian Peninsula during the Republic", The Western Roman Atlantic Façade. A study of the Economy and Trade in the Mar Exterior from the Republic to the Principate, Britisch Archaeologycal Repords, In. Ser., 2162 (Carreras, C. y Morais, R., eds.), Oxford, 135-143.

Fabião, C. (2007), "El ejército romano en Portugal”, El ejército romano en Hispania, Guía Arqueológica (Morillo, A., ed.), León, 113-134.

Fernández Corrales, J. M. (1987), "Las explotaciones mineras como factor de la romanización en Extremadura”, Alcántara, 10, Cáceres, 99-107.

Fernández Corrales, J. M. (1988), “Minería y asentamientos romanos en Extremadura: su problemática”, Alcántara, 15, Cáceres, 107-116.

Fernández Corrales, J. M. (1989), "Territorios urbanos y asentamientos mineros en Extremadura”, Alcántara, 16, Cáceres, 131-139.

Fernández Jurado, J. y Ruíz Mata, D. (1995), “La metalurgia de la plata en época tartésica en Huelva”, Pyrenae, 21, 23-44.

Fernández Jurado, J. (1993), "Plata y plomo en el comercio fenicio-tartésico", Metalurgia en la Península Ibérica durante el primer milenio a. C. Estado actual de la investigación, (Arana, R. y otros, eds.), Murcia, 131-165.

Fernández Ochoa, C. y Zarzalejos Prieto, M.(2003), "Minería romana y estrategias de poblamiento en el sector central de Sierra Morena”, Defensa y territorio en Hispania. De los Escipiones a Augusto, (Morillo, A., Cadiou, F. y Hourcade, D., eds.), León, 253-272.

Fernández Ochoa, C., Zarzalejos Prieto, M., Burkhalter Thiébaut, C., Hevia Gómez, P. y Esteban Borrajo, G. (2002), Arqueominería del 
sector central de Sierra Morena. Introducción al estudio del área Sisaponense, Anejos de Archivo Español de Arqueología, XXVI, Madrid.

Fernández Rodríguez, M. y García Bueno, C. (1993), "La minería romana de época republicana en Sierra Morena: El poblado de Valderrepisa (Fuencaliente, Ciudad Real)", Malanges de la Casa de Velázquez, 29, I, 25-50.

Frank, T. (1959), An Economic Survey of Ancient Rome, vol. I, Rome and Italy of the Republic, Nueva Jersey.

Frank, T. (1914), Roman Imperialism, Kitchener.

Frank, T. (1933a), An Economic Survey of Ancient Rome, vol. I, Rome and Italy of the Republic, Baltimore.

Frank, T. (1933b), "The activities of the Equistran Corporations, 200-150 B.C.”, Classical Philology, XXVIII, vol. 1, Chicago, 1-11.

Gabba, E. (1954), "Le origini della Guerra Sociale e la vita política romana dopo 189 A.C. Sull'emigrazione romano-italica in Spagna nel II sec. A.C.", Athenaeum, 32, 297-305.

Gabba, E. (1973), Esercito e società nella tarda repubblica romana, Florencia.

García Romero, J. (2002), Minería y metalurgia en la Córdoba romana, Universidad de Córdoba, Córdoba.

García Vargas, E., Ferrer Albelda, F. J. y García Fernández, F. J. (2008), "La romanización del Bajo Guadalquivir: ciudad territorio y economía (siglos II-I a. C.)”, Mainake, 30, 247-270.

García-Bellido, M. P. (1982), Las monedas de Cástulo con escritura indígena. Historia numismática de una ciudad minera, Barcelona.

García-Bellido, M. P. (1995), "Celtas y púnicos en la Beturia según sus documentos monetarios", Celtas y túrdulos: La Beturia, Cuadernos Emeritenses, 9, Mérida, 255-292.

González Cordero, A. y Heras Mora, F. J. (2010), "El castro de Botija y sus minas. Una revisión historiográfica de la obra de Clemente Roswag”, Actas del IV Encuentro de Arqueología del Suroeste Peninsular (Pérez Macías, J. A. y Romero Bomba, E., coords.), Huelva, 881-912.

Heras Mora, F. J. (2015), Arqueología de la implantación romana en los cursos Tajo-Guadiana (siglos II-I a.n.e.), U. Autónoma de Barcelona, Tesis doctoral inédita.

Hernández Hernández, F. y Galán Domingo, E. (1996), La necrópolis de El Mercadillo, (Bo- tija, Cáceres), Extremadura Arqueológica, VI, Mérida.

Hernández Hernández, F. (1993), "La necrópolis de 'El Romazal', Plasenzuela (Cáceres)”, Homenaje a J. $M^{a}$ Blázquez, II, Madrid, 257-270.

Hernández Hernández, F., Galán Domingo, E. y Martín Bravo, A. M. (2008), "La necrópolis prerromana de El Romazal I (Plasenzuela, Cáceres)", Arqueología Vettona: La Meseta Occidental en la Edad del Hierro, Zona Arqueológica, 12, Madrid, 323-336.

Hernández Hernández, F., Rodríguez López, M. D. y Sánchez Sánchez, M. A. (1989), Excavaciones en el castro de Villasviejas del Tamuja (Botija, Cáceres), Mérida.

Hunt Ortiz, M. A. (1988), "La recuperación de la plata del speiss en Río Tinto", Huelva en su Historia, 2, Huelva, 147-160.

Hunt Ortiz, M. A. (1995), "El foco metalúrgico de Aznalcóllar, Sevilla. Técnicas analíticas aplicadas a la arqueometalurgia del Suroeste de la Península Ibérica”, Tartessos 25 años después (1968-1993), Jerez de la Frontera, 447-473.

Hunt Ortiz, M. A. (2000), "Las primeras evidencias de la utilización del plomo en la metalurgia extractiva de la plata en la zona suroccidental de la Península Ibérica", Actas del I Simposio sobre la Minería y la Metalurgia Antigua en el $S W$ Europeo, Serós 2.6, 161-167.

Izquierdo de Montes, R. (1997), "Sobre la copelación de la plata en el mundo tartésico”, Spal, 6, Sevilla, 87-101.

Jiménez Ávila, F. J. (1990a), Estudio arqueológico del poblado de Hornachuelos (Ribera del Fresno, Badajoz) y su entorno, Memoria de Licenciatura inédita.

Jiménez Ávila, F. J. (1990b), Estudio numismático del poblado de Hornachuelos (Ribera del Fresno, Badajoz), Series de Arqueología Extremeña, 4, Cáceres.

Jiménez Ávila, J. (1989-90), "Notas sobre la minería romano-republicana bajoextremeña: las explotaciones de plomo de la Sierra de Hornachos (Badajoz)”, Anas, 2-3, Mérida, 123-134.

Kay, P. (2014), Rome's Economic Revolution, Oxford.

López Sánchez, F. (2014), “Apiano y la moneda celtibérica”, La Guerre et ses traces. Conflits et sociétés en Hispanie à l'époque de la conquête romaine (III ${ }^{e} I^{e} s$. av. J.-C.), Université de Bordeaux III (Cadiou, F. y Navarro, M. eds.), 
Bordeaux, 395-413.

López Sánchez, F. (2010), "Moneda ibérica y gens mariana (107-90 a.C.)”, Gladius, 171-190.

López Sánchez, F. (2007), "Los auxiliares de Roma en el Valle del Ebro y su paga en denarios ibéricos (133-90 a.C.)", Athaenaeum, 95, 287-319.

López-Mondéjar, L. (2009), "Los castella tardorrepublicanos del Noroeste murciano en el marco del paisaje comarcal del siglo I a. C.: control del territorio y romanización en el Sureste peninsular”, Zephyrus, LXIV, Salamanca, 97-113.

Maia, M. G. P. y Maia, M. (1996), "Os castella do Sul de Portugal e a mineração da prata nos primórdios do imperio”, Mineração no Baixo Alentejo, Castro Verde, 60-81.

Maia, M. (1986), "Os castella do Sul de Portugal”, Madrider Mitteilungen, 27, Mainz, 195-223.

Mangas, J. y Orejas, A. (1999), "El trabajo en las minas en la Hispania romana", El trabajo en la Hispania romana (Rodríguez Neila, J. F., González Román, C., Mangas, J. y Orejas, A., eds.), Ed. Sílex, 207-337.

Marcos Alonso, C. (1993), "Monedas halladas en el yacimiento de Valderrepisa (Fuencaliente, Ciudad Real). Apéndice”, Mélanges de la Casa de Velázquez, 29-1, Madrid, 42-50.

Morillo Cerdán, A. y Salido Domínguez, J. (2010), "El aprovisionamiento del ejército romano en Hispania. Transporte, almacenaje y redistribución”, Militares y civiles en la antigua Roma: dos mundos diferentes, dos mundos unidos (Palao Vicente, J. J., ed.), Salamanca, 135-164.

Murcia Muñoz, A. J., Brotóns Yagüe, F. y García Sandoval, J. (2008), "Contextos cerámicos de época republicana procedentes de enclaves militares ubicados en la cuenca del Argos-Quípar en el noroeste de la Región de Murcia (España)", Iberia e Italia: modelos romanos de integración territorial. Actas del IV Congreso Hispano-italiano, (Uroz Sáez, J., Noguera Cerdán, J. M., Coarelli, F., eds.), Murcia, 73-87.

Naco del Hoyo, A. (2001), "Milites in oppidis hibernabant: El hospitium militare invernal en ciudades peregrinas y los abusos de la hospitalidad sub tectis durante la República”, Dialogues d'histoire ancienne, 27, 2, 63-90.

Naco del Hoyo, T. (2003), Vectigal Incertum. Economía de guerra y fiscalidad republicana en el Occidente mediterráneo: su impacto en el territorio (218-133 a. C.), BAR International Series, 1158, Oxford.
Ñaco del Hoyo, T. (2007), “The Late Republican West: imperial taxation in the making?", Actas del $7^{\circ}$ Workshop del International Network Impact of Empire 'Crises and the Roman Empire' (Nijmegen 2006), (Hekster, O., Kleijn, G. y Slootjes, D., eds.), Leiden-Boston, 219-231. Ñaco del Hoyo, T. (2010-11), "Roma y el impacto de su ejército en la Hispania republicana: un enfoque "total", Faventia, 32-33, 297-305.

Ñaco del Hoyo, T. (2010a), "Garrisons, military logistics and civil population in the Late Republic: Africa and Hispania", The Western Roman Atlantic Façade: A Study of the Economy and Trade in Mar Exterior from the Republic, BAR. International Series, 2162, (Carreras Monfort, C. y Morais, R., eds.), Oxford, 145-150. Naco del Hoyo, T. (2010b), "The Republican War Economy Strikes Back: a 'minimalist' approach", Administrer les provinces de la République romaine, 1, (Kirbihler, F. y Barrandon, N., eds.), Rennes, 171-180.

Naco del Hoyo, T., Principal, J. (2012), “Outposts of integration? Garrisoning, Logistics and Archaeology in N.E. Hispania, 133-82 BCE”, Integration and Identity in the Roman Republic (Roselaar, S., ed.), Leiden-Boston, 159-177.

Nicolet, C.(1979), "Deux remarques sur'organisation des sociétés de publicains á la fin de la République Romaine", Points de vue sur la fiscalité antique, París, 69-95.

Ortiz Romero, P. y Rodríguez Díaz, A. (1998), "Culturas indígenas y romanización en Extremadura: Castros, oppida y recintos ciclópeos", Extremadura Protohistórica. Paleoambiente, economía y poblamiento, Cáceres, 247-278.

Otero Morán, P. (1993), "Consideraciones sobre la presencia de acuñaciones celtibéricas en zonas mineras de la Hispania Ulterior”, Actes du XI Congrès International de Numismatique, Bruselas 1991, Lovain-la-Neuve, 49-58.

Paniego Díaz, P. (2014), “Apuntes sobre la minería del hierro en Burguillos del Cerro (Badajoz)", Extremadura, Revista de Historia $1<$ http:/ extremadurarevistadehistoria.com>, 247-259.

Passelac, M. (2002), "Le mobilier céramique de La Loba. Vaiselle de table et de cuisine, lampes et autres objets de terre cuite", La Loba (Fuenteobejuna, Cordoue, Espagne). La Mine et le village minier antiques, Ausonius Memories, 7 (Blázquez Martínez, J. M., Domergue, C. y Sillières, P., dirs.), Bordeaux, 231-293. 
Pastor Muñoz, M., Pachón Romero, J. A. y Carrasco Rus, J. (1992), Mirobriga. Excavaciones Arqueológicas en el "Cerro del Cabezo" (Capilla, Badajoz). Campañas 1987-1988, Mérida.

Pérez Macías, J. A. y Delgado Domínguez, A. (2007a), "Los metalla de Riotinto en época Julio-claudia", en Las minas de Riotinto en época Julio-Claudia (Pérez Macías, J. A. y Delgado Domínguez, A., eds.), Publicaciones de la Universidad de Huelva, Huelva, 35-182.

Pérez Macías, J. A. y Delgado Domínguez, A. (2007b), "Tecnología metalúrgica en Riotinto y Suroeste Ibérico desde la Edad del Bronce hasta la Edad Media”, Colloque d'AnnabergBuchholz, Val de Marne, 281-300.

Pérez Macías, J. A. y Delgado Domínguez, A. (2009), "El castellum de El Castillejo (El Campillo, Huelva): la explotación romano-republicana en Riotinto", Río Tinto. Historia, Patrimonio Minero y Turismo Cultural (Pérez Macías, J. A., Delgado Domínguez, A., Pérez López, J. M. y García Delgado, F. J., eds.), Huelva, 47-73.

Pérez Macías, J. A. (1987), Carta Arqueológica de los Picos de Aroche, Huelva.

Pérez Macías, J. A. (1991), "La fundición protohistórica de Monte Romero en Almonaster la Real, Huelva", Cuadernos del Suroeste, 2, Huelva, 99-129.

Pérez Macías, J. A. (1995), "Poblados, centros mineros y actividades metalúrgicas en el cinturón ibérico de piritas durante el Bronce Final”, Tartessos 25 años después (1968-1993), Jerez de la Frontera, 417-446.

Richardson, J. S. (1976), "The mines and the development of provincial taxation in the second century B. C.”, The Journal of Roman Studies, 66, 139-152.

Rodríguez Díaz, A. e Iniesta Mena, J. (1984), “Las Dehesillas, un yacimiento prerromano en $\mathrm{Hi}$ guera de Llerena (Badajoz)", Norba, Revista de Historia, 5, Cáceres, 17-28.

Rodríguez Díaz, A. y Enríquez Navascués, J. J. (2001), Extremadura tartésica. Arqueología de un proceso periférico, Ed. Bellaterra Arqueología, Barcelona.

Rodríguez Díaz, A. y Jiménez Ávila, F. J. (1990), "Informe sobre las excavaciones realizadas en el yacimiento de Hornachuelos, Ribera del Fresno (Badajoz). 1986-1988”, Norba, Revista de Historia, 8-9, Cáceres, 13-31.
Rodríguez Díaz, A. (1987), El poblamiento prerromano en la Baja Extremadura, Tesis Doctoral inédita, Universidad de Extremadura.

Rodríguez Díaz, A. (1992), "Proyecto Hornachuelos: 1986- 1990 (Ribera del Fresno, Badajoz)”, Actas I Jornadas de Prehistoria y Arqueología en Extremadura (1986-1990), Extremadura Arqueológica II, Mérida-Cáceres, 283- 300.

Rodríguez Díaz, A. (1995), “Territorios y etnias prerromanas en el Guadiana Medio: aproximación arqueológica a la Beturia túrdula", Celtas y túrdulos: La Beturia, Cuadernos Emeritenses, 9, Mérida, 205-254.

Rodríguez Díaz, A., coord. (1991), La Ermita de Belén (Zafra, Badajoz), Campaña 1987, Mérida.

Rovira, S. (1995), "De metalurgia tartésica”, Tartessos 25 años después (1968-1993), Jerez de la Frontera, 475-506.

Sánchez Abal, J. L., García Jiménez, S. (1988), “La ceca de Tanusia", en Actas del I Congreso Peninsular de Historia Antigua (Pereira, G., ed.), Santiago de Compostela, 149-190.

Tejada Olaya, M. A. (1997), Historia de Garlitos, Ed. Samat, Badajoz.

Torres Escobar, C. y Gutiérrez Soler, L. M. (2004), "Poblamiento Ibérico Tardío en la provincia de Jaén. Dos casos de estudio: el Arroyo Salado de Los Villares y los Castilletes de Sierra Morena”, Torres, atalayas y casas fortificadas. Explotación y control del territorio en Hispania ( $S$. III a. de C. - S. I de C.), (Moret, P. y Chapa, T., eds.), Jaén, 133-144.

Vaquerizo Gil, D. et alii (1994), Arqueología cordobesa. El valle del Alto Guadiato (Fuenteobejuna, Córdoba), Córdoba.

Villaronga, L. (1977), Los tesoros de Azaila y la circulación monetaria en el Valle del Ebro, Asociación Numismática Española, Barcelona.

Villaronga, L. (1979), Numismática Antigua de Hispania, Barcelona.

Villaronga, L. (1990), "El hallazgo de monedas. El caso de Tamusia", Gaceta Numismática, 9798, Barcelona, 79-86.

VV. AA. (1993), La Minería en Extremadura, Junta de Extremadura, Badajoz.

VV. AA. (2007), Mapa metalogenético de Extremadura. Escala1:250.000. Junta de Extremadura, Madrid.

VV.AA. (2009), El Patrimonio Minero de Extremadura. 
Zarzalejos Prieto, M., Fernández Ochoa, C., Hevia Gómez, P. y Esteban Borrajo, G. (2012a), "El área de Almadén (Ciudad Real) en el territorio de Sisapo. Investigaciones arqueo-históricas sobre las etapas más antiguas de explotación del cinabrio hispano", De Re Metallica, 19 (julio-diciembre, 1e época), 67-78.

Zarzalejos Prieto, M., Fernández Ochoa, C., Hevia Gómez, P. y Esteban Borrajo, G. (2012b), "El paisaje minero antiguo de la comarca de Almadén (Ciudad Real). Nuevas aportaciones sobre el territorio de Sisapo", Minería y metalurgia antiguas, visiones y revisiones. Homenaje a Claude Domergue (Orejas, A. y Rico, C., eds.), Casa de Velázquez, Madrid, 129-150. 